\title{
ZAŠTITA POSLOVNIH TAJNI KAO OBLIKA INTELEKTUALNOG VLASNIŠTVA
}

Doc. dr. sc. Ana Rački Marinković*

\author{
UDK 347.77 .038 \\ https://doi.org/10.30925/zpfsr.40.2.5 \\ Ur.: 9. svibnja 2019. \\ Pr.: 5. lipnja 2019. \\ Izvorni znanstveni rad
}

\section{Sažetak}

Pojmovno se definiraju poslovne tajne $i$ objašnjavaju karakteristike $i$ specifičnosti njihove zaštite. Poslovne se tajne razmatraju u kontekstu intelektualnog vlasništva, te ih se uspoređuje s drugim, formalnim pravima intelektualnog vlasništva. Sagledava se kako je zaštita poslovnih tajni uređena na međunarodnom planu te se analiziraju odredbe Direktive EU 2016/943 o zaštiti neotkrivenih znanja i iskustva te poslovnih informacija (poslovne tajne) od nezakonitog pribavljanja, korištenja i otkrivanja, kao i razlozi za njezino donošenje. Govori se o važnosti njihove zaštite za poslovanje, osobito za poticanje inovacija. Prikazuje se na koji je način spomenuta Direktiva implementirana i kako je uspostavljen sustav zaštite poslovnih tajni kao oblika intelektualnog vlasništva u Republici Hrvatskoj donošenjem Zakona o zaštiti neobjavljenih informacija s tržišnom vrijednosti. Naposljetku, razmatra se primjena Direktive o provedbi prava intelektualnog vlasništva na povrede poslovnih tajni. Ukazuje se da je važnost Direktive EU 2016/943 prije svega u harmonizaciji pravila građanskopravnog postupka, dok će u tumačenju opsega zaštite poslovnih tajni i predviđenih iznimaka značajnu ulogu imati sudska praksa.

Ključne riječi: poslovne tajne; know-how; intelektualno vlasništvo; nepošteno trgovanje.

\section{1. $U V O D$}

U poslovanju često razne informacije bilo da se radi o određenom znanju i iskustvu (know-how), ili o poslovnim ili tehnološkim informacijama pomažu tvrtkama koje tim informacijama raspolažu ostvariti prednost u odnosu na njihove konkurente. Zbog prednosti na tržištu koje nositelj poslovne tajne ostvaruje držanjem tih informacija u tajnosti takva informacija posjeduje određenu tržišnu (komercijalnu) vrijednosti.

* Doc. dr. sc. Ana Rački Marinković, Ured zastupnika Republike Hrvatske pred Europskim sudom za ljudska prava, armarinkovic@zastupnik-esljp.hr. 
Znanje i iskustvo (know-how), poslovna ili tehnološka informacija koja predstavlja poslovnu tajnu u osnovi je određena intelektualna tvorevina. Kako pokazuju aktualne studije, ${ }^{1}$ tvrtke češće svoje inovacije štite u okviru alternativnih mogućnosti zaštite kao što je zaštita poslovnih tajni nego kroz formalne oblike prava intelektualnog vlasništva kao što su patent, industrijski dizajn ili žig. Suprotno značaju koje u poslovanju gospodarskih subjekta evidentno imaju, u usporedbi s drugim pravima intelektualnog vlasništva poslovne tajne uvelike su manje istražene i obrađene.

Stoga će se u ovom radu poslovne tajne promatrati u svjetlu intelektualnog vlasništva te će se prikazati po čemu se one razlikuju a po kojim su obilježjima slične pravima intelektualnog vlasništva. Pored toga pokazat će se kako zaštita poslovnih tajni može biti komplementarna, ali i alternativna zaštita nekim od formalnih prava intelektualnog vlasništva. Pretpostavka je da svaki od ovih oblika zaštite ima određene mane ili nedostatke, ali i prednosti koje poslovni subjekti trebaju sagledati pri odlučivanju na koji način štititi svoje intelektualno vlasništvo.

Na razini Europske unije donošenjem nove Direktive EU 2016/943 o zaštiti neotkrivenih znanja $\mathrm{i}$ iskustva te poslovnih informacija (poslovne tajne) od nezakonitog pribavljanja, korištenja i otkrivanja ${ }^{2}$ predviđena su ujednačena pravila koja se tiču zaštite poslovnih tajni kako bi se pridonijelo predvidivosti poslovanja i razvitku zajedničkog tržišta. Pretpostavka je da će se novom Direktivom ojačati i harmonizirati zaštita poslovnih tajni na unutarnjem tržištu, pa će se pokušati utvrditi koji su dosezi i prednosti spomenute Direktiva po pitanju zaštite i provedbe poslovnih tajni. Pritom je bitan i način na koji je spomenuta Direktiva implementirana u nacionalno zakonodavstvo pa će se u radu prikazati i kako je općenito uspostavljen sustav zaštite poslovnih tajni u zakonodavstvu Republike Hrvatske.

\section{POSLOVNE TAJNE KAO OBLIK INTELEKTUALNOG VLASNIŠTVA}

Kada se poslovne tajne razmatraju u kontekstu intelektualnog vlasništva obično se naglašava da pojam intelektualnog vlasništva obuhvaća prava intelektualnog vlasništva koja se dijele na industrijsko vlasništvo s jedne i autorska i srodna prava s druge strane, dok poslovne tajne kao i drugo, tzv. neformalno intelektualno vlasništvo predstavljaju intelektualno vlasništvo u širem smislu koje u pravilu ne karakterizira postojanje subjektivnog isključivog prava apsolutne naravi. ${ }^{3}$ Takvi neformalizirani

1 Studija Intelektualno vlasništvo (IV) i rezultati malih i srednjih poduzeća za 2016. godinu (engl. Intellectual property (IP) SME Scoreboard 2016) koju je objavila Europska promatračnica za povrede prava intelektualnog vlasništva (EU Observatory) pri Uredu Europske unije za intelektualno vlasništvo (EUIPO), dostupno na: https://euipo.europa.eu/ohimportal/en/web/ observatory/sme-scoreboard-2016 (18. veljače 2019.).

2 Direktiva (EU) 2016/943 Europskog parlamenta i Vijeća od 8. lipnja 2016. o zaštiti neotkrivenih znanja i iskustva te poslovnih informacija (poslovne tajne) od nezakonitog pribavljanja, korištenja i otkrivanja (Tekst značajan za EGP), SL L 157, 15.6.2016, str. 1-18.

3 Matanovac Vučković, R., Zbirka propisa u području prava intelektualnog vlasništva, Zagreb, Narodne novine/Državni zavod za intelektualno vlasništvo, 2008., str. 5. 
oblici zaštite intelektualnog vlasništva kao što je zaštita od nepoštenog tržišnog natjecanja ili zaštita poslovnih tajni dijele s pravima intelektualnog vlasništva određene karakteristike, ali nisu nikakvo isključivo, monopolno pravo kao što je to karakteristično kod formalnih prava intelektualnog vlasništva.

Poslovne su tajne istodobno i jedno od prava osobnosti poduzetnika. U tom kontekstu pravo na zaštitu poslovne tajne osobno je, neimovinsko pravo koje nositelju daje potpunu privatnopravnu vlast glede činjenica i vrijednosnih sudova zaštićenih poslovnom tajnom, te ovlast da svakoga isključi od protupravnog narušavanja toga njegovog prava osobnosti. ${ }^{4} \mathrm{U}$ okviru prava osobnosti ne štiti se tajna sama po sebi, nego osobnost u koju se nepovlasno zadire njezinim odavanjem. ${ }^{5}$

Pravna zaštita poslovne tajne pretpostavlja postojanje instituta kojom će se ona zaštititi u slučaju povrede. Pritom se zaštita u slučaju povrede poslovne tajne s aspekta prava osobnosti očituje u naknadi prvenstvo neimovinske štete, dok se zaštita $\mathrm{s}$ aspekta prava intelektualnog vlasništva očituje u naknadi prvenstveno imovinske štete nastale nezakonitim pribavljanjem, korištenjem i otkivanjem poslovnih tajni. ${ }^{6}$

U radu će se ograničiti na razmatranje poslovnih tajni u kontekstu intelektualnog vlasništva. Pritom valja naglasiti da se zaštita poslovnih tajni kao intelektualnog vlasništva ostvaruje samo u odnosu na one poslovne tajne koje imaju određenu komercijalnu vrijednost. Naime poslovni subjekti često u svom poslovanju raspolažu i određenim informacijama koje drže u tajnosti, iako nemaju komercijalnu vrijednost. Međutim, takve se informacije upravo zbog toga što nemaju komercijalnu vrijednost ne bi mogle kvalificirati kao intelektualno vlasništvo.

Određene osobne informacije o zaposlenicima ili kupcima kao što su primjerice zdravstveni kartoni djelatnika, osobni podatci i podatci vezani za načine plaćanja moraju se čuvati tajnima, sukladno važećim propisima, no takvi podatci nisu intelektualno vlasništvo. Takve informacije nemaju komercijalnu vrijednost niti njima poduzeća ostvaruju prednost na tržištu. No, primjerice lista kupaca, odnosno klijenata može osiguravati određenu prednost na tržištu, pa se time kvalificira i kao poslovna tajna u smislu intelektualnog vlasništva.

Niti one informacije koje se saznaju u obavljanju profesionalne dužnosti nisu intelektualno vlasništvo jer iako se moraju čuvati u tajnosti slijedom obveze čuvanja profesionalne tajne, kao što su primjerice bankarska, odvjetnička ili liječnička tajna, nisu informacije s kojima bi njihov stjecatelj smio raspolagati, pa takve profesionalne informacije ne mogu imati komercijalnu vrijednost.

U okviru kategorije poslovnih informacija koje se čuvaju u tajnosti ne mora se uvijek raditi o informacijama koje bi se mogle kvalificirati kao poslovne tajne u smislu intelektualnog vlasništva. Naime u okviru širega pojma poslovne tajne obuhvaćene su i druge vrste povjerljivih poslovnih informacija koje nemaju nužno komercijalnu vrijednost. Poslovne tajne kao oblik intelektualnog vlasništva kompleksnije su informacije koje imaju komercijalnu vrijednost za razliku od onih povjerljivih

4 Miladin, P., Poslovna i profesionalna tajna kao prava osobnosti, u: Zbornik radova: pravo na pristup informacija - Novalja 30-31. svibnja 2008., Split, str. 112.

5 ibid., str. 110.

6 Slično tomu povreda žiga kao prava intelektualnog vlasništva istodobno može biti i povreda prava osobnosti u vidu prava na ugled pravne osobe koja je nositelj tog žiga. 
informacija poslovnih subjekata koje se drže u tajnosti zbog određenih poslovnih razloga, ali nemaju takvu komercijalnu vrijednost.

Poslovne tajne koje se odnose na takve kompleksnije (netrivijalne) informacije, koje imaju gospodarsku, odnosno komercijalnu (tržišnu) vrijednost, uobičajeno se nazivaju trade secret, za razliku od šireg pojma poslovne tajne koji obuhvaća i druge vrste povjerljivih poslovnih informacija, a koja se uobičajeno naziva business secret. U hrvatskom jezičnom izričaju uobičajeno se oba pojma (engl. trade secret i business secret) nazivaju i prevode kao „poslovna tajna“, uz rjeđe korištenje termina ,trgovačka tajna“" za poslovnu tajnu s gospodarskom vrijednosti (engl. trade secret). ${ }^{7}$

Poslovne informacije koje se mogu kvalificirati kao poslovne tajne u smislu intelektualnog vlasništva i podvesti pod definiciju poslovnih tajni često su podatci koji se odnose na proizvodni postupak, know-how, sastojke proizvoda, rezultate istraživačkog rada, popis klijenata, sadržaj ugovora, poslovnu politiku, podatci sadržani u internom izvješćivanju, procjenama, poslovnim planovima; uzorci, prototipovi, ogledni primjerci, radna oprema itd. Radi se o doista vrlo širokom i raznovrsnom spektru informacija koje ne uključuju samo tehnološko znanje, već i informacije bitne za stvaranje i korištenje takozvanih „mekih” inovacija za konkurentnost, kojima su obuhvaćeni korištenje i primjena raznolikog raspona strateških poslovnih informacija, kao što su informacije o klijentima i dobavljačima, poslovnim procesima, poslovnim planovima, istraživanju tržišta itd. ${ }^{8}$

Često se u kontekstu podataka koji se uobičajeno čuvaju kao poslovne tajne spominje know- how. Taj se engleski izraz kao pojam uobičajeno koristi u poslovnim krugovima u svijetu te u literaturi, a u službenim dokumentima na hrvatskom jeziku prevodi se kao „znanje i iskustvo“.9 Ponekad se pojmovi poslovne tajne i know-how

7 Iz obrazloženja Prijedloga zakona o zaštiti neotkrivenih informacija i iskustava te poslovnih informacija kojeg je Hrvatskom saboru 9. studenog 2017. godine podnijela Vlada Republike Hrvatske , str. 1., dostupno na: https://www.sabor.hr/sites/default/files/uploads/ sabor/2019-01-18/081314/PZE_225.pdf (28. lipnja 2019).

8 Iz obrazloženja Prijedloga direktive o zaštiti neotkrivenih znanja i iskustava, te poslovnih informacija (poslovne tajne) od nezakonitog pribavljanja, korištenja i otkrivanja, $\operatorname{COM}(2013) 813$, Brisel, 28. studenog 2013. godine, str. 3, dostupno na: https://eur-lex.europa. eu/LexUriServ/LexUriServ.do?uri=COM:2013:0813:FIN:HR:PDF (23. kolovoz 2018). S obzirom na ovu raznovrsnost informacija neki autori pokušali su razložiti i podijeliti pojmovno njihovu zaštitu pa tako primjerice Hamidović, H. u: Nije zaštićeno? Ne može biti otuđeno!, OpeninfoTrend, 7, 2016., dostupno na: http://www.infotrend.hr/clanak/2016/7/nije-zasticenone-moze-biti-otudeno!-,88,1258.html (23. kolovoza 2018.), razlikuje proizvodne tajne koje bi se odnosile na postupak proizvodnje ili konstrukciju uređaja, od poslovnih tajni koje se tiču knjigovodstva, lista nabavnih izvora, klijenata, poslovnih partnera i slično. U Verona, A., Pravo industrijskog vlasništva, Zagreb, Informator, 1978., na str. 124-125, također se razlikuju tehnički know-how i poslovni i trgovački know-how.

9 Više o tome u Verona, op. cit., str. 123. Zakon o zaštiti neobjavljenih informacija s tržišnom vrijednosti (NN, br. 30/18.) u članku 3. stavku 2. koristi pojam „znanje i iskustvo“. Tako i službeni prijevod na hrvatski jezik Uredbe Komisije (EU), br. 316/2014 od 21. ožujka 2014. o primjeni članka 101. stavka 3. Ugovora o funkcioniranju Europske unije na kategorije sporazuma o prijenosu tehnologije (SL L 93, 28.3.2014, str. 17-23) u članku 1. stavku 1. točki i). 
smatraju čak i sinonimima, ${ }^{10}$ no bitno je istaknuti da je pojam znanja i iskustva koliko god široko shvaćen samo jedna od vrsta podataka koje mogu biti smatrane poslovnom tajnom kao oblikom intelektualnog vlasništva. S druge strane, know-how ne mora nužno biti tajan ${ }^{11}$ i može se odnositi i na određene vještine i stručne sposobnosti koje su u određenim specijaliziranim krugovima postale opće poznate. ${ }^{12}$ Stoga bi samo ona znanja i iskustva koja poslovni subjekti čuvaju u tajnosti mogli biti kvalificirani kao poslovna tajna. ${ }^{13}$

\section{DEFINICIJA POSLOVNE TAJNE}

Poslovnu tajnu nije moguće definirati popisivanjem i propisivanjem onih podataka i informacija koji može biti poslovna tajna. Stoga se definicija poslovne tajne daje navođenjem bitnih elemenata koje takva informacija mora zadovoljiti da bi se kvalificirala kao poslovna tajna u smislu intelektualnog vlasništva. Naočigled slična vrsta informacija stoga će jednom zadovoljavati uvjetima za zaštitu poslovne tajne, a drugi put ne. Kako bi se ostvarila kao oblik intelektualnog vlasništva poslovna tajna ne smije biti razotkrivena u javnosti, mora imati komercijalnu vrijednost zbog toga što je tajna te moraju biti poduzeti odgovarajući postupci kako bi se osigurala njihova tajnost.

Ova je definicija poslovne tajne usuglašena na međunarodnom planu i sadržana

10 IPR Helpdesk, How to manage confidential business information, Fact Sheet, lipanj 2015., str. 2., dostupno na: https://www.iprhelpdesk.eu/sites/default/files/newsdocuments/FactSheet-How-to-Manage-Confidential-Business-Information.pdf (23. kolovoza 2018.). U literaturi i stručnim krugovima nalazimo primjere poistovjećivanja poslovnih tajni kao oblika intelektualnog vlasništva i know-how. Primjerice Matanovac, op. cit., str. 4-5, govori o zaštiti znanja i iskustva (know-how) u kontekstu zaštite poslovnih tajni. U starijoj literaturi Verona, op. cit., str. 123-134, raspravljalo se o zaštiti posebnog oblika intelektualnog vlasništva koji karakterizira tajnost i njegova komercijalna vrijednost zbog toga što je tajan te kojemu valja stoga pružiti odgovarajuću zaštitu u vezi s know-how, dok se pojam poslovnih tajni nije koristio. Raspravljalo se o tome je li tajnost bitan element zaštite takvog know-howa. Zaštita poslovnih tajni kao pojma širega pojmu znanja i iskustva te s tajnošću kao preduvjetom zaštite razvila se kasnije.

11 U Uredbi Komisije (EU), br. 316/2014 (bilješka 9) „znanje i iskustvo” definira se kao skup praktičnih podataka koji je nastao kao rezultat iskustva i ispitivanja i koji je: tajan, odnosno nije općepoznat ili lako dostupan; odnosno važan i koristan za proizvodnju ugovornih proizvoda i prepoznatljiv, odnosno opisan na dovoljno opširan način kako bi bilo moguće provjeriti ispunjava li kriterije tajnosti i važnosti. Ipak valja istaknuti da je doseg ove definicije ograničen na primjenu same Uredbe. Iz sadržaja Uredbe i načina na koji je pojam znanja i iskustva korišten može se zaključiti da se tako pojmovno definirano znanje i iskustvo koristi kao sinonim za poslovne tajne.

12 Radni dokument Europske komisije „Procjena učinka Prijedloga direktive o zaštiti neotkrivenih znanja i iskustava, te poslovnih informacija (poslovne tajne) od nezakonitog pribavljanja, korištenja i otkrivanja“, SWD (2013) 471 od 28. studenog 2013. godine dostupan na: https:// eur-lex.europa.eu/legal-content/EN/TXT/?uri=CELEX:52013SC0471 (23. kolovoza 2018.), Dodatak/Aneks 1, str. 108. U kontekstu znanja iskustva koje čine vještine i stručne sposobnosti ulazimo već u domenu implicitnog znanja (engl. tacit knowledge) koji se prije svega veže za ljudske resurse i smatra se intelektualnim kapitalom nekoga poslovnog subjekta.

13 Tako i IPR Helpdesk (bilješka 10), str. 2. 
u Sporazumu o trgovinskim aspektima prava intelektualnog vlasništva (dalje u tekstu: Sporazum TRIPS). ${ }^{14}$ Taj je međunarodni ugovor ujedno i prvi koji spominje zaštitu neobjavljenih informacija u kontekstu zaštite intelektualnog vlasništva ${ }^{15}$ kao instrument osiguravanja učinkovite zaštite protiv nepoštene tržišne utakmice. Pritom se u okviru članka 39. koji predviđa zaštitu neobjavljenih informacija stavkom 2. definira generalna obveza zaštite poslovnih tajni. U stavku 3. posebno se osigurava zaštita podataka o lijeku koje je proizvođač lijeka dao nadležnom tijelu za izdavanje odobrenja za stavljanje lijekova na tržište. Valja napomenuti da odredba članka 39. stavka 3. Sporazuma TRIPS obvezuje države na zaštitu takvih podataka od nepoštene komercijalne uporabe ne propisujući niti duljinu trajanja takve zaštite podataka niti se izrijekom odnosi na zabranu pozivanja konkurenata na rezultate toksikoloških i farmakoloških ispitivanja te rezultate kliničkih ispitivanja. ${ }^{16}$ Ipak većina razvijenih država pruža ekskluzivnu zaštitu podatcima koji se odnosi na rezultate toksikoloških i farmakoloških ispitivanja te rezultate kliničkih ispitivanja tijekom određenog vremena. Proizvođač generičkoga lijeka može se pozvati na navedene podatke proizvođača izvornog lijeka i ishoditi odobrenje za stavljanje lijeka u promet ako dokaže da je lijek istovrstan onom izvornoga proizvođača tek nakon proteka tog razdoblja zaštite podataka. Razdoblje ekskluzivne zaštite ovih podataka poznat je i kao data exclusivity institut ${ }^{17}$ i smatra se višom razinom zaštite od obvezujuće po Sporazumu TRIPS. ${ }^{18}$

14 Agreement on Trade-Related Aspects of Intellectual Property Rights, od 15. travnja 1994. je Aneks 1C Marakeškog ugovora o osnivanju Svjetske trgovinske organizacije (WTO) kao rezultata pregovora Urugvajske runde. Sporazum TRIPS nije objavljen u Narodnim novinama. Službeni prijevod na hrvatski jezik nalazimo u posebnom izdanju pravne stečevine na hrvatskom jeziku objavljenom povodom pristupanja Republike Hrvatske Europskoj uniji Poglavlje 11. Vanjski odnosi, Sv. 074, dostupno na: https://eur-lex.europa.eu/legal-content/HR/ TXT/?uri=celex:21994A1223(17) (23. kolovoza 2018.).

15 Dotadašnji horizontalni relevantni ugovori u području kao što su Pariška konvencija za zaštitu industrijskog vlasništva od 20. ožujka 1883 te Konvencija kojom se osniva Svjetska organizacija za intelektualno vlasništvo od 14. srpnja 1967. u listi prava industrijskog odnosno intelektualnog vlasništva koju donose ne spominju poslovne tajne.

16 Meitinger, I., Burri, M., Protection of Undisclosed Information, Commentary of Article 39 of the Agreement on Trade-Related Aspects of Intellectual Property Rights (TRIPS"), str. 5-6, u: Cottier, T., Véron, P., Concise International and European IP Law: TRIPS, Paris Convention, European Enforcement and Transfer of Technology, The Hague, Kluwer Law International, Hague, 2014., dostupno na: https://ssrn.com/abstract=2439180 (23. listopada 2018.). U tom kontekstu države nisu dužne pružati ekskluzivnu zaštitu podataka već obvezi propisanoj Sporazumom TRIPS udovoljavaju i kad rezultate toksikoloških i farmakoloških ispitivanja te rezultate kliničkih ispitivanja štite samo u okviru pravila o zabrani nepoštenog trgovanja. Proizvođači generičkoga lijeka stoga se mogu pozvati na navedene podatke proizvođača izvornog lijeka i ishoditi odobrenje za stavljanje lijeka u promet dokazivanjem da su njihovi proizvodi istovjetni originalnom proizvodu bez da su im ti podatci bili dostupni odnosno ne smiju do njih doći nepošteno.

17 Naziv korišten i u obrazloženju Zakona o izmjenama i dopunama zakona o lijekovima i medicinskim proizvodima dostupno na: https://vlada.gov.hr/UserDocsImages//Sjednice/ Arhiva//52-11.pdf (23. kolovoza 2018.).

18 Correa, C. M., Test data protection, u Dreyfuss, Rochelle, C. i Strandburg, K. J. (ur.), The Law and Theory of Trade Secrecy, A Handbook of Contemporary Research, Cheltenham, Edward Elgar Publishing, 2011., str. 568-590 detaljno opisuje razlike u shvaćanju dosega odredbe 
Odredba članka 39. stavka 2. Sporazuma TRIPS usklađuje zaštitu poslovnih tajni na međunarodnom planu određivanjem osnovnih karakteristika zaštite poslovnih tajni kao oblika intelektualnog vlasništva. Zaštita se pruža u slučajevima kada je poslovna tajna otkrivena protivno poštenoj trgovačkoj praksi. Zaštita poslovnih tajni za razliku od tradicionalnih prava intelektualnog vlasništva stoga ne stvara nikakvo apsolutno isključivo pravo slično kao i zaštita od nepoštenog trgovanja, pa se utoliko odredba članka 39. Sporazuma TRIPS smatra i svojevrsnom podvrstom zaštite od nepoštenog trgovanja. ${ }^{19}$ Upravo zbog toga veliki broj država zaštitu poslovnih tajnu u prvom redu osigurava u sklopu propisa kojima se osigurava zaštita od nepoštenoga trgovanja. ${ }^{20}$

Definicija sadrži nekoliko bitnih sastavnica: mora se raditi o informaciji koja je tajna, ima komercijalnu vrijednost i poduzeti su razumni koraci da bi ju se sačuvalo u tajnosti. Svi ti elementi moraju biti zadovoljeni da bi se neka informacija mogla smatrati poslovnom tajnom kao oblikom intelektualnog vlasništva. Sporazum TRIPS obvezuje sve države članice Svjetske trgovinske organizacije pa tako i Europsku uniju, stoga ovu definiciju preuzima i Direktiva EU 2016/943 o zaštiti neotkrivenih znanja $\mathrm{i}$ iskustva te poslovnih informacija (poslovne tajne) od nezakonitog pribavljanja, korištenja i otkrivanja kao i Zakon o zaštiti neobjavljenih informacija s tržišnom vrijednosti kojim je u nacionalno zakonodavstvo Republike Hrvatske implementirana ta Direktiva.

članka 39. stavka 3. Sporazuma TRIPS. Iako su Sjedinjene Američke Države i Europska unija agresivno promicale teoriju po kojoj Sporazum TRIPS ovim stavkom obvezuje države na uvođenje, tzv. data exclusivity, odnosno ekskluzivne zaštite podataka testiranja lijekova originalnih proizvođača lijekova, činjenica je da brojne zemlje u razvoju koje su članice WTO-a nisu uvele ovaj institut, a protiv njih nisu bili pokrenuti sporovi zbog povrede Sporazuma TRIPS kroz mehanizme koje predviđa sam sporazum. Takva je, ekskluzivna zaštita podataka iz kliničkih testiranja lijekova, smatra, zaštita povrh Sporazuma TRIPS a koju naziva TRIPS-plus zaštitom. Na razliku između zaštite podataka (engl. data protection) prema članku 39. stavku 3. Sporazuma TRIPS i ekskluzivne zaštite podataka (engl. data exclusivity) kakva postoji u Europskoj uniji upozoravaju i Adamini, S., et al., Policy Making on Data Exclusivity in the European Union: From Industrial Interests to Legal Realities, Journal of Health Politics, Policy and Law, vol. 34, 6, prosinac 2009., str. 986.

19 Tako i Meitinger, op. cit., str. 2.

20 Tako Zakon o trgovini (NN, br. 87/08., 116/08., 76/09., 114/11., 68/13. i 30/14.) u članku 63. sadrži opću klauzulu zabrane nepoštenog trgovanja, dok u članku 64. u primjeričnom nabrajanju radnji koje se smatraju nepoštenim trgovanjem navodi i ,protupravno pribavljanje poslovne tajne drugog trgovaca ili bespravno iskorištavanje povjerene poslovne tajne drugog trgovca“. Prethodnim Zakonom o trgovini (NN, br. 11/96., 75/99., 76/99., 62/01., 109/01., 49/03., 96/03. i 103/03.) u članku 70. i članku 71. u okviru zabrane nepoštenog tržišnog natjecanja nalazimo u odnosu na zaštitu poslovne tajne odredbe jednakog sadržaja. Zabrana nelojalne konkurencije bila je regulirana u starom Zakonu o trgovini (NN, br. 53/91., 77/92. i 26/93.) kojim je preuzet Zakon o trgovini iz Službenog lista 46/90. Analiza sadržana u Radnom dokumentu Komisije, (bilješka 12), str. 64, pokazuje da je i većina drugih država članica Europske unije neovlašteno otkivanje poslovnih tajni regulirala u okviru svojih zakona kojim se zabranjuje nepošteno trgovanje (Austrija, Bugarska, Češka,, Njemačka, Danska, Estonija, Grčka, Španjolska, Finska, Mađarska, Latvija, Litva, Poljska, Rumunjska, Slovačka i Slovenija). 


\subsection{Tajnost informacije}

Ova odrednica definicije osnovni je uvjet zaštite poslovnih tajni. Kao što izum mora biti nov da bi ga se zaštitio patentom, znak razlikovan da bi ga se registriralo kao žig, a autorsko pravo originalno, tako informacija u prvom redu mora biti tajna, ${ }^{21}$ premda trebaju biti zadovoljeni i ostali propisani uvjeti. Tako tajnost svakako treba i dokazati što se u praksi ponekad može ne činiti bitnim ili se može olako shvatiti. ${ }^{22}$ Iz navedenoga slijedi da paušalna i općenita pozivanja na tajnost ne bi bila dopuštena, pa stoga ne bi, primjerice bilo moguće cjelokupno poslovanje tvrtke proglasiti poslovnom tajnom.

Informacija mora biti tajna $u$ smislu da nije u svojoj ukupnosti ili u točnoj strukturi i sklopu svojih sastavnih dijelova, općenito poznata ili lako dostupna osobama iz krugova koji se obično bave predmetnom vrstom informacija. Pritom se ne definira o kojoj se vrsti informacije radi, već se može raditi u načelu o bilo kojoj vrsti informaciji bilo poslovnoj ili tehnološkoj. Ne traži se da je informacija apsolutno tajna što bi pretpostavljalo da je poznata samo svome nositelju. Informacija koja bi morala biti apsolutno tajna ne bi imala nikakvu važnost jer se njome ne bi moglo raspolagati, stoga se traži relativna ili supstancijalna tajnost. ${ }^{23}$ Osim nositelja poslovne tajne sadržaj poslovne tajne mogu znati i drugi, ali ona ne smije biti općepoznata ili lako dostupna osobama iz krugova koji se obično bave predmetnom vrstom informacija. To znači da smije biti poznata određenog krugu ljudi, ali se ne može nalaziti u javnoj domeni. Krug ljudi koji znaju sadržaj informacije treba biti brojčano ograničen, iako nije moguće odrediti neku gornju granicu o kojem se broju smije raditi, no sve osobe kojima su te informacije poznate moraju biti na određeni način obvezatni čuvati njenu tajnost. Dio definicije po kojem se tajnost očituje u tome da informacija ne smije biti „lako dostupna osobama iz krugova koji se obično bave predmetnom vrstom informacija“, odnosi se na svojevrsnu stvarnu dostupnost informacija koja proizlazi iz kvalitete i prirode tih informacija odnosno mogu li se lako pronaći u objavljenim materijalima. ${ }^{24}$

21 Risch, M., Trade secret law and information development incentives, u: Dreyfuss, op. cit., str. 167.

22 Lemly, M., A. The surprising virtues of treating trade secrets as IP rights, u: Dreyfuss, op. cit., str. 131-132, navodi niz presuda iz sudske prakse SAD-a u kojima su sudovi zanemarivali utvrditi radi li se uopće o tajnim informacijama te su se fokusirali na postojanje određenog poslovnog odnosa tužitelja i tuženika te zaključili da postoji povreda iz same činjenice što je tuženik narušio obvezu čuvanja tajne iz tog odnosa a da su pritom uopće utvrdili je li informacija tajna ili čak i ako je ona bila dostupna javnosti utvrdili da postoji odgovornost tuženika iz činjenice da je ta ugovorna obveza povrijeđena. Ukazuje da prvi korak u sporu zbog povrede poslovne tajne mora biti utvrđivanje tajnosti, a ne postojanje obveze čuvanja poslovne tajne. Dokazivanjem tajnosti kao pretpostavkom zaštite, poslovne tajne ispravno se, smatra, tretiraju kao intelektualno vlasništvo, jer je kod svih prava intelektualnog vlasništva pretpostavka povrede postojanje samog prava, dok se u suprotnom ponajprije štite poslovni odnosi povjerenja, što ostaje u okviru zaštite nepoštenog trgovanja.

23 Sandeen, S., K., The limits of trade secret law: Article 39 of the TRIPS Agreement and the Uniform Trade Secret Act on which it is based, u: Dreyfuss, op. cit., str. 555.

24 Kao što su trgovački časopisi i knjige ili drugi objavljeni proizvodi. Iz Sadeen, op. cit., str. 555. Za razliku od toga Meitinger, op. cit., str. 2, smatraju da se ovaj dio definicije odnosi na čuvanje 
Ne mora se nužno raditi samo o onim informacijama koje su tajne u cjelini, već i onda kada se radi o informacijama čiji dijelovi nisu tajni, ali način na koji su oni sastavljeni nije poznat javnosti. To je, primjerice slučaj s nekim bazama podataka u koje se unose elementi koji nisu tajni, ali način na koji su te baze sastavljene jesu tajne „u točnoj strukturi i sklopu svojih sastavnih dijelova“. Nekada informacija može djelomično biti otkrivena javnosti, a samo jedan njen dio, pod uvjetom da se može odgovarajuće specificirati i izdvojiti, ostaje tajan, ili je informacija otkrivena određenim zainteresiranim krugovima, ali ne i široj javnosti, pa možemo govoriti o svojevrsnoj relativnoj tajnosti. ${ }^{25}$

\subsection{Komercijalna vrijednost}

Drugi uvjet koji mora biti zadovoljen da bi se radilo o poslovnoj tajni kao obliku intelektualnog vlasništva jest da tajna informacija ima komercijalnu vrijednost upravo jer je tajna. Ovo je onaj element definicije koji poslovne tajne kao intelektualno vlasništvo razgraničava od poslovnih tajni u širem smislu koje ne moraju nužno imati komercijalnu vrijednost. Upravo je komercijalna vrijednost koja proizlazi iz tajnosti ona prednost na tržištu nositelja u usporedbi s njegovim konkurentima i ona kvaliteta koja tim informacijama daje karakter intelektualnog vlasništva. Poslovne tajne u širem smislu također su tajne informacije, međutim one nemaju komercijalnu vrijednost per $s e{ }^{26}$ već bi njihovo otkrivanje vjerojatno štetilo interesima nositelja, a taj interes je vrijedan pružanja zaštite. Komercijalna vrijednost informacije budući da je ona tajna znači da nositelj ima komercijalni interes držati tu informaciju u tajnosti, jer time ostvaruje prednost na tržištu koju ne bi imao da njegovi konkurenti znaju sadržaj te informacije. Kod poslovnih tajni kao oblika intelektualnog vlasništva taj je interes komercijalan i objektivan, ${ }^{27}$ dok se kod poslovnih tajni u širem smislu može raditi o nekom drugom interesu koji nužno ne mora niti biti objektivan. U tom se kontekstu i takvim informacijama pruža zaštita, ${ }^{28}$ ali ne u okviru zaštite intelektualnog vlasništva, jer im nedostaje komercijalna vrijednost da bi ih se moglo smatrati intelektualnim vlasništvom.

Pritom bi se trebalo uzeti u obzir da komercijalna vrijednost tajne informacije

tajnosti ne samo poduzetih od strane nositelja poslovne tajne nego općenito u krugu osoba koji se obično bave predmetnom vrstom informacije.

25 Cornish, W., Llewelyn, D., Intellectual property: Patents, Copyright, Trade Marks and Allied Rights, London, Sweet \& Maxwell, 2003., str. 308, navodi da o okolnostima slučaja ovisi hoće li će sud priznati zaštitu takvih relativno tajnih informacija.

26 Iz Radnog dokumenta Komisije (bilješka 12), str. 113.

27 Cornish, op. cit., str. 326 navode da ukoliko se povreda ekonomskog interesa nositelja kod povrede poslovne tajne utvrđuje na osnovi subjektivnog kriterija ona bi se mogla sastojati i od povrede njegovih osjećaja zbog povrede poslovne tajne što otvara nova pitanja o pravnoj prirodi zaštite poslovnih tajni. Smatramo da bi takva zaštita spadala u domenu zaštite prava osobnosti a ne zaštite poslovnih tajni kao oblika intelektualnog vlasništva.

28 Opći sud Europske unije u Luxembourgu u predmetu T-353/94 Postbank protiv Europske komisije EU:T:1996:1 postavio je te kriterije za zaštitu poslovnih tajni u širem smislu. Sve presude Suda Europske unije dostupne su na: https://curia.europa.eu (30. listopada 2018.). 
može biti stvarna ili potencijalna. ${ }^{29}$ Člankom 2. Direktive EU 2016/943 propisano je da komercijalna vrijednost mora proizlaziti iz toga što su informacije tajne. $U$ točki 14. preambule naglašava se da takva komercijalna vrijednost može biti stvarna ili potencijalna. Primjerično se navodi da informacije imaju komercijalnu vrijednost kada bi njihovo nezakonito pribavljanje, korištenje ili otkrivanje moglo naštetiti interesima osobe koja ih zakonito kontrolira jer se time narušavaju znanstveni i tehnički potencijal, poslovni ili financijski interesi, strateške pozicije ili sposobnost tržišnog natjecanja. ${ }^{30}$ Trebalo bi uzeti da komercijalnu vrijednost imaju i informacije koje su negativne, primjerice dugotrajnim i skupim istraživanjem ustanovljeno je da neki postupak za proizvodnju jednostavno nije optimalan ili uopće ne radi, pa takva informacija može biti iznimno korisna konkurentima.

Kada se uzme u obzir da je skup podataka i informacija koje mogu biti smatrane poslovnim tajnama neodređen i nije ih moguće definirati popisivanjem i propisivanjem, dok komercijalna vrijednost koja takve podatke i informacije definira kao oblik intelektualnog vlasništva može biti i potencijalna, postavlja se realna opasnost da ova odrednica u praksi potpuno izgubi važnost. Moglo bi se, naime tvrditi da svaka informacija ili podatak koji je tajan u konačnici može potencijalno imati određenu, makar minimalnu, komercijalnu vrijednost. Činjenica što nositelj poslovne tajne smatra potrebnim zaštititi svoju poslovnu tajnu pravnim putem, mogla bi argumentirati postojanje takve komercijalne vrijednosti. ${ }^{31}$ Time bi se u potpunosti izgubila ona karakteristika poslovnih tajni kao oblika intelektualnog vlasništva koja ih razdvaja od drugih podataka i informacija koje se drže tajnim u poslovanju, a koje nemaju takvu vrijednost. Na kraju, ako teoretski svaka informacija i podatak koji je tajan zaslužuje zaštitu onda se štiti povreda tajnosti, pa predmet zaštite postaje tajna informacija, a ne ulaganje utrošeno u njen razvoj i određena komercijalna vrijednost odnosno tržišna prednost koju donosi, čime gubi poveznicu s drugim pravima intelektualnog vlasništva. ${ }^{32}$ Pri procjeni ovoga kriterija, stoga treba biti vrlo oprezan te je na sudskoj praksi da osigura da se komercijalna vrijednost utvrđuje na

29 Tijekom pregovora oko teksta Sporazuma TRIPS kako to opisuje Sandeen, op. cit., str. 549- 552, razmatrano je da se u odredbi članka 39. stavka 2. točke b) regulira „potencijalna“ komercijalna vrijednost. Ipak i bez ovog izričitog dodatka smatra da ta vrijednost ne mora nužno biti stvarna već i potencijalna jer u većini situacija poslovne tajne i nisu u komercijalnom prometu te se samo potencijalno može govoriti o njihovoj vrijednosti. Ako bi se radilo isključivo o stvarnoj komercijalnoj vrijednosti, zaštita poslovnih tajni uskratila bi se cijelom nizu tajnih informacija koje se drže u tajnosti u domorodačkim zajednicama. Naime, takve se informacije uglavnom unutar zajednica drže u tajnosti zbog drugih interesa, uglavnom religijskih, ali osobe izvan tih krugova mogu imati komercijalni interes u vezi sa sadržajem tih informacija. Više o tome u: Long, D. E., Trade secrets and traditional knowledge: strengthening international protection of indigenous innovation, u: Dreyfuss, op. cit., str. 522.

30 Isto je propisano Zakonom o zaštiti neobjavljenih informacija s tržišnom vrijednosti (članak 3. stavak 1. točka 5. i stavak 3. istoga članka).

31 Tako Meitinger, op. cit., str. 3.

32 Trebalo bi uzeti u obzir da komercijalnu vrijednost mogu imati i informacije koje su negativne. Primjerice konkurentima može biti izuzetno korisna informacija da neki postupak za proizvodnju nije optimalan ili uopće ne radi, a što je ustanovljeno dugotrajnim i skupim istraživanjem, prema Van Overwalle, G., Uncorking trade secrets: sparking the interaction between trade secrecy and open biotechnology, u: Dreyfuss, op. cit., str. 250. 
osnovi objektivnog interesa potrebe čuvanja tajnosti te da tražena razina komercijalne vrijednosti bilo stvarne ili potencijalne bude postavljena ne previsoko, ali ipak dostatno visoko da izuzme od zaštite trivijalne informacije i osigura zaštitu samo onih poslovnih tajni koje se mogu smatrati intelektualnim vlasništvom.

\subsection{Razumne mjere za očuvanje tajnosti}

Ovaj je uvjet već na prvi pogled prilično kontradiktoran, pa se često propitkuje opravdanost njegova postojanja. ${ }^{33}$ Naime postavlja se pitanje zašto je uopće potrebna pravna zaštita poslovnih tajni kada su već poduzete mjere za očuvanje tajnosti? Tim više što se zaštita konvencionalnih prava intelektualnog vlasništva načelno pruža nositeljima tih prava neovisno o tome jesu li poduzeli mjere za zaštitu svojih prava od trećih osoba pa je ovaj uvjet svojevrsne samopomoći neobičan i u usporedbi s drugim oblicima intelektualnog vlasništva. ${ }^{34}$

Neki autori smatraju da potreba poduzimanja mjera za očuvanje tajnosti kako bi se pružila pravna zaštita poslovnih tajni proizlazi iz činjenice što poslovne tajne ne pružaju isključivo pravo svojemu nositelju. Zbog toga smatraju da je jedino opravdano pravnu zaštitu pružati samo onim poslovnim tajnama koje štiti i njihov nositelj ${ }^{35}$ i time trećima obznani da se radi o zaštićenim podatcima i informacijama. ${ }^{36}$ Obrazloženje takvog uvjetovanja pravne zaštite po nekima se krije upravo u obvezi poduzimanja „razumnih“ mjera za očuvanje tajnosti. Činjenica da se traži poduzimanje razumnih koraka zamjenjuje obvezu poduzimanja mjera potpune zaštite tajnosti. Pravna zaštita nastupa nakon što je nositelj poduzeo razumne mjere za očuvanje tajnosti ${ }^{37}$ pa nositelj

33 Bone, R. G., Trade secrecy, innovation and reasonable secrecy precautions, u: Dreyfuss, op. cit., str. 46-76, nakon iscrpne analize zaključuje da ne nalazi opravdanje postojanju ovog uvjeta.

34 Zaštita autorskog prava pružit će se bez potrebe enkripcije mrežne stranice na kojoj se djelo nalazi, zaštita srodnih prava umjetnika izvođača pruža se, iako posjetitelji koncerta/predstave nisu pretraženi imaju li skrivene snimatelje zvuka ili slike, dapače zaštita nije uvjetovana niti stavljanjem obavijesti da je takva reprodukcija ili snimanje zabranjeno, pa niti time da se naznači da je djelo zaštićeno autorskim pravom ili srodnim pravima. Jednako tako nositelj patenta ne mora pokazati da je treće pokušao spriječiti u proizvodnji, korištenju, prodaji ili uvozu predmeta izuma prije nego je zatražio pravnu zaštitu. Bone, op. cit., str. 47.

35 Tako Meitinger, op. cit., str. 3 smatra da se samo nositelj koji je poduzeo mjere za zaštitu svojih poslovnih tajni, pa su treće osobe morale uložiti određeni trud da zaobiđu i prevladaju te mjere čime su dokazale svoju nepoštenu namjeru prema takvim zaštićenim informacijama, može pouzdati i u njihovu pravnu zaštitu. McMullen, D., J., Torok, G., Recipe for reasonable measures, Intellectual Property Magazine, listopad 2016., dostupno na: https://www. intellectualpropertymagazine.com/patent/recipe-for-reasonable-measures-119892.htm veljače 2019.), pak smatraju da se nepoduzimanje razumnih mjera može smatrati nemarom nositelja kojim se doprinosi nastanku štete (engl. contributory negligence).

36 Donekle usporedivo sa stavljanjem, tzv. copyright notice, odnosno oznake, ,sva prava pridržana“ na primjerke autorskih djela čime je bila uvjetovana zaštita autorskih prava u nekim državama primjerice Sjedinjenim Američkim Državama do pristupanja Bernskoj konvenciji za zaštitu književnih i umjetničkih djela (dostupna na: https://www.dziv.hr/files/File/zakonodavstvo/ medjunarodni/Bernska_konvencija.pdf (13. veljače 2019.)).

37 Pritom se nameće pitanje nije li samopomoć u tom slučaju s obzirom na karakteristike poslovnih tajni učinkovitija i smislenija zaštita od pravne. Naime, poslovne tajne nisu isključivo pravo nositelja te ako se poslovna tajna otkrije pravna zaštita u pravilu dolazi prekasno jer bez obzira 
ne mora uvesti stroga fizička ograničenja i uspostaviti potpunu izolaciju kako bi apsolutno onemogućio da se dođe do tih informacija, što bi inače morao primijeniti da učinkovito očuva tajnost takvih informacija.

Zaključuje se da potreba poduzimanja razumnih koraka za očuvanje tajnosti, iako istovremeno ima učinak obznanjivanja trećima da podatke i informacije ne smiju pribavljati, koristiti i otkrivati bez pristanka nositelja takve poslovne tajne, pretpostavlja pružanje pravne zaštite kojom se uklanja potreba za poduzimanjem ekstremnih mjera za očuvanje tajnosti koje bi bile povezane s velikim troškovima te negativno utjecale na razvoj poslovanja i inovativnost. ${ }^{38}$

S obzirom na praktični aspekt primjene ovog uvjeta potrebno je sagledati koje su to mjere za očuvanje tajnosti koje će se smatrati razumno potrebne da se očuva tajnost. One prije svega ovise o okolnostima slučaja, pa je nemoguće unaprijed definirati razinu zaštite tajnosti koje nositelji moraju poduzeti kako bi zadovoljili ovaj uvjet pružanja pravne zaštite. Direktiva EU 2016/943 ne govori ništa detaljnije o tome, no u Zakonu o zaštiti neobjavljenih informacija s tržišnom vrijednosti $u$ članku 3., pri definiciji pojmova u stavku 4. navedeno je da takvi razumni koraci mogu uključivati izradu internog akta o rukovanju poslovnom tajnom i krugu osoba te njihovim pravima i obveza kod rukovanja poslovnom tajnom ili mjere fizičke ili virtualne zaštite pristupa i rukovanja poslovnom tajnom. Iako se radi o primjeričnom nabrajanju te zbog činjenice da procjena koji su to koraci potrebni ovisi prvenstveno o okolnostima, donekle je nositeljima dano do znanja što bi mogli poduzeti za zaštitu poslovnih tajni. Sadržajno se radi o uspostavi internih procesa kojim se osigurava zaštita poslovnih tajni, te mjerama fizičke ili virtualne zaštite koje se mogu uspostaviti.

Procjena prije svega ovisi o okolnostima slučaja, na što utječe vrsta informacije koja se čuva tajnom, posebnosti industrijskog sektora u kojem se poslovna tajna javlja, uključujući rizik od neovlaštenog pribavljanja poslovne tajne u tom sektoru, ali i vrijednost same poslovne tajne. Trebalo bi uzeti da što je komercijalna vrijednost poslovne tajne veća, to bi mjere koje se očekuju da nositelj poduzme trebale biti na višoj razini. U tim bi okolnostima razumne mjere trebale bi biti sofisticiranije, skuplje sveobuhvatnije nego u slučajevima poslovnih tajni koje nemaju veću vrijednost. Pri procjeni jesu li poduzete mjere bile razumne u obzir treba uzeti postojeće dostupne zaštitne mjere i trošak njihova poduzimanja u razmjeru s vrijednošću poslovne tajne. ${ }^{39}$

Jedan od najpoznatijih primjera poslovne tajne sastav je bezalkoholnog napitka Coca-Cola, ujedno jedna od najvrjednijih poslovnih tajni u svijetu. ${ }^{40}$ Mjere koje

na zahtjeve koje nositelj ima prema onome tko ju je nezakonito pribavio, koristio ili otkrio ne može ju ostvarivati erga omnes i ne može ju ponovo učiniti tajnom ako je već postala javno dostupna.

38 Bone, op. cit., smatra da, iako se čini nerazumno, jedino donekle logično opravdanje postojanja ovog uvjeta upravo je u tome što primjena razumnih mjera umjesto učinkovitije zaštite poslovnih tajni služi kako bi se pospješila diseminacija takvih informacija i time obogatila javna domena, čime se potiče inovativnost.

39 Meitinger, op. cit., str. 3.

40 Nirwan, P., Trade secrets: the hidden IP right, WIPO Magazine, 6, prosinac 2017., dostupno na: http://www.wipo.int/wipo_magazine/en/2017/06/article_0006.html (13. veljače 2019.). Madison, M., J., Open secrets, u: Dreyfuss, op. cit., str. 222 navodi kako je poslovna tajna koju čini receptura ovog bezalkoholnog napitka osnova za više milijuna dolara prodaje potrošačima 
kompanija poduzima kako bi recept očuvala tajnim već preko stotinu godina postali su urbana legenda. ${ }^{41}$ Ipak, to nisu uobičajene mjere koje će se očekivati od nositelja poslovnih tajni kako bi zadovoljili traženu razinu razumnih mjera. No, s druge strane razumnost mjera utvrđuje se prema objektivnom kriteriju, pa jednako tako nije niti dovoljno da nositelj poduzme samo one mjere koje on subjektivno misli da osiguravaju tajnost, a koje objektivno nisu dostatne. ${ }^{42}$ Važnost ovoga uvjeta pružanja zaštite tim je veći jer ovisi o djelovanju nositelja, dakle radi se o uvjetu na koji nositelj direktno svojim postupanjem može utjecati.

Iako bi sa stajališta nositelja sigurnije bilo poduzeti što veću razinu sigurnosti i mjera kada govorimo o potrebnoj razini mjera koje bi se mogle smatrati razumnim postoje određene preporuke koje bi trebali slijediti. Nositelji poslovne tajne trebali bi imati uspostavljen odgovarajući interni program upravljanja i zaštite poslovnim tajnama, pri čemu je bitan aspekt uspostava interne politike zaštite poslovnih tajni i identifikacije informacija koje se smatraju poslovnim tajnama kompanije. ${ }^{43}$ Pojednostavljeno, nositelj mora prije svega točno znati koje su to tajne informacije koje posjeduje i čuva u tajnosti, a koje za njega imaju komercijalnu vrijednost. Nakon toga treba uspostaviti mjere kojima će takve informacije zaštititi od otkrivanja. Takve se mjere mogu podijeliti u tri bitne cjeline: mjere fizičke zaštite, mjere zaštite u odnosu na svoje zaposlenike i mjere zaštite prema svojim poslovnim partnerima. ${ }^{44}$

Mjerama fizičke zaštite osigurava se u pravilu da povjerljive informacije ne dođu u ruke trećih osoba s kojima nositelj nema ugovorni odnos. Ovdje se u pravilu govori o tehničkim mjerama koje imaju za cilj da treće osobe ne mogu doći do sadržaja informacija koje čine poslovne tajne. Primjerice, pristup elektroničkim dokumentima osiguran je upotrebom lozinke, ${ }^{45}$ informacije u fizičkom obliku drže se $\mathrm{u}$ zaključanim prostorijama te se osobe koje ulaze $\mathrm{u}$ te prostorije moraju evidentirati i slično. U tu vrstu mjera ubrajaju se i posebne procedure uspostavljene radi zaštite poslovnih tajni od trećih: primjerice zabrana preslika ili drugih načina umnožavanja takvih informacija, obveza uništavanja dokumenata koje sadrže poslovne tajne i slično. S obzirom na to da je rizik odavanja informacija veći što je veći krug osoba kojem su poslovne tajne poznate ovdje bi se mogle ubrojiti i mjere koje se sastoje od ograničenja pristupa informacijama samo određenom užem krugu zaposlenika

diljem svijeta.

41 Smatra se da cjelovita formula nije nikome poznata, već se čuva zapisana u trezoru u Atlanti, a dvoje ljudi zna svaki po polovicu formule i ta dvojica nikada ne smiju putovati istim avionom, dostupno na: https://bdjls.org/coca-colas-secret-formula-trade-secret-kept-century/ (14. veljače 2019.). Trezor se nalazi u muzeju i može biti posjećen, dostupno na: https://www.cocacolacompany.com/stories/the-secret-is-out-coca-colas-formula-is-at-the-world-of-coca-cola (13.veljače 2019.).

42 McMullen, op. cit., str. 42.

43 Detaljnije IPR Helpdesk, op. cit., str. 6-10.

44 ibid., str. 7-9.

45 S obzirom na specifičnost industrijskog sektora, kod poslovnih tajni koje se javljaju u industriji programiranja softvera takve će mjere fizičke zaštite moći biti određene tehničke mjere, poput tehnologija obfuskacije ili skrivanja koje izvorni kod čine nerazumljivim ili vezanje za softvere za praćenje izvršenja programa ili softvere za utvrđivanje profila programa iz: McMullen, op. cit., str. 42. 
(prema need-to-know principu), posebna ograničenja ulaska u prostore gdje se koriste poslovne tajne i tako dalje.

Mjere zaštite u odnosu na zaposlenike čine u pravilu pravne mjere. Čak i ako smo mjerama fizičke zaštite ograničili krug osoba kojima su poslovne tajne dostupne, ipak određene osobe u obavljanju svojih poslova moraju koristiti poslovne tajne i nužno moraju poznavati sadržaj poslovnih tajni. Njih se mora pravno obvezati na čuvanje tajnosti takvih informacija te predvidjeti ugovornu odgovornost u slučaju povrede obveze čuvanja tajnosti. Takve će se klauzule o povjerljivosti najčešće nalaziti u ugovoru o radu, ali mogu biti primjenjive i slijedom odredaba kolektivnih ugovora $\mathrm{i}$ pravilnika o radu. Za otkrivanje poslovne tajne veliki su rizik bivši zaposlenici koji se zaposle kod konkurencije. ${ }^{46}$ Stoga se ugovorna zabrana konkurencije ${ }^{47}$ također smatra jednom od mjera zaštite poslovnih tajni. Zaposlenike treba i obučiti za rukovanje poslovnom tajnom, prije svega upoznati ih s predviđenim mjerama fizičke zaštite te ih obvezati da ih se pridržavaju. Identifikacija poslovnih tajni ovdje ima bitnu ulogu jer zaposlenik može poduzeti predviđene mjere i držati tajnim informacije, samo ako je svjestan da se radi o informacijama koje su poslovna tajna.

Mjere zaštite prema poslovnim partnerima također su pravne, bilo da se radi o posebnim ugovorima o čuvanju tajnosti, odnosno ugovorima o povjerljivosti podataka ${ }^{48}$ bilo da se radi o klauzulama povjerljivosti koje nalazimo u ugovorima kojima se regulira neki poslovni odnos ${ }^{49}$ te pretpostavljaju jasno označavanje informacija koje se smatraju poslovnim tajnama pri otkrivanju partnerima u poslovnim odnosima.

\subsection{Opseg zaštite}

Ranije je već spomenuto kako poslovne tajne nisu isključivo pravo. Isključivo pravo pretpostavlja pravo nositelja na isključivo iskorištavanje predmeta zaštite i

46 Andrews J., et al., Keep quiet and carry on under the EU trade Secrets Directive, Intellectual Property Magazine, rujan 2016., dostupno na: https://www.intellectualpropertymagazine.com/ world/europe/keep-quiet-and-carry-on-under-the-eu-trade-secrets-directive-119136.htm (14. veljače 2019.) navode da se odavanje poslovnih tajni od strane bivših zaposlenika načelno smatra najvećim pojedinačnim uzrokom povrede poslovnih tajni.

47 Pod uvjetima pod kojim je ona dopuštena prema nacionalnom radnom zakonodavstvu. U Republici Hrvatskoj članci 102.-105. Zakona o radu (NN, br. 93/14. i 127/17.) reguliraju ovu materiju.

48 Često se u poslovanju susrećemo s raznim nazivima ovakvih ugovora budući da se radi o tzv. neimenovanim ugovorima, kojima za razliku od nominatnih (imenovanih) ugovora nije određen i propisan naziv i sadržaj. U engleskom nalazimo tako na, tzv. secrecy agreement, confidentiality agreement ili non-disclosure agreement. Takvi ugovori mogu biti namijenjeni jednostranoj ili dvostranoj razmjeni poslovnih tajni, kod kojih svaka strana drugoj otkriva određene informacije koje su tajne i obostrano se obvezuju na čuvanje tajnosti informacija koje su dobili od druge strane.

49 To će najčešće biti ugovor o licenciji, ugovor o zajedničkom pothvatu, ugovor o distribuciji, ugovor o franšizi, ugovor o ugovornoj proizvodnji te ugovor o provedbi kliničkih ispitivanja. Kod nekih poslovnih odnosa takvim se ugovorom, uz obvezu čuvanja tajnosti informacija s kojima je svaka od stranka ušla u poslovni odnos, mora urediti i pravni status zajedničkih poslovnih tajni koje nastanu kroz takvu poslovnu suradnju. To obuhvaća ne samo obvezu čuvanja tajnosti takvih informacija već i kome će one pripasti. 
mogućnost da svakog trećega spriječi da se njime koristi. Opseg zaštite takvih prava djeluje erga omnes, pa svaka treća osoba koja takva prava povrjeđuje s obzirom na njegov opseg zaštite može u tome biti spriječena. Opseg zaštite poslovne tajne ne ovlašćuje nositelja poslovne tajne da svaku treću osobu spriječi u korištenju poslovne tajne, dakle zaštita nije apsolutna. No, iako poslovne tajne nisu isključivo pravo, njihov nositelj ostvaruje stvarni monopol nad sadržajem poslovne tajne za vrijeme dok ih čuva tajnima. ${ }^{50}$

Opseg zaštite prema odredbi članka 39. Sporazuma TRIPS obuhvaća otkrivanje, pribavljanje i uporabu drugih bez pristanka nositelja pod uvjetom da su protivni poštenoj trgovačkoj praksi. Otkrivanje poslovnih tajni sastojat će se u povredi koju počine zaposlenici, bivši zaposlenici ili poslovni partneri koji mimo preuzetih obveza čuvanja poslovne tajne otkriju sadržaj informacije. Povredu poslovne tajne pribavljanjem čine pak treće osobe koje su sadržaj poslovne tajne saznale od osoba koje su povrijedile obvezu čuvanja tajnosti otkrivanjem ili su ga pribavile činom industrijske špijunaže. ${ }^{51}$ Uporabi poslovne tajne kojom se čini povreda u pravilu će prethoditi neovlašteno pribavljanje ili otkrivanje takve poslovne tajne. Da bi se radilo o povredi dodatno svi takvi postupci moraju biti protivni poštenoj trgovačkoj praksi. Iako ne čini sastavni dio odredbe članka 39. kroz bilješku na ovaj dio odredbe nabrojeni su oni postupci koje države u najmanju ruku trebaju smatrati protivnima poštenoj trgovačkoj praksi. To su kršenje ugovornih obveza, kršenje obveze čuvanja tajnosti i poticanje na takvo kršenje, što uključuje stjecanje neotkrivenih informacija od osoba koje znaju ili su zbog grube nepažnje propustile saznati, da je stečeno takvom praksom.

Iako je veliki broj država Europske unije zaštitu poslovnih tajnu osiguravalo u sklopu propisa kojima se osigurava zaštita od nepoštenog trgovanja, neke su imale posebne zakone o zaštiti poslovnih tajni, neke su odredbe o zaštiti poslovnih tajni ugradile u svoje zakone o zaštiti intelektualnog vlasništva ili bi povredu poslovnih tajni sankcionirale kao delikt. ${ }^{52}$ Svakim od navedenih načina udovoljeno je obvezi prema Sporazumu TRIPS, no usprkos tome postojale su znatne razlike u načinu na koji se pružala zaštita poslovnim tajnama. ${ }^{53}$

50 Poslovne se tajne i kod primjene propisa o zaštiti tržišnog natjecanja izjednačavaju s drugim pravima intelektualnog vlasništva u kontekstu zabrane nedozvoljenih monopola, sukladno odluci Prvostupanjskog suda u predmetu T-201/04 Microsoft protiv Europske komisije od 17. rujna 2007., dostupno na: http://curia.europa.eu/juris/showPdf. jsf;jsessionid=30D76B4AB7DF8D6982510C073E92FCDA?text=\&docid=62940\&pageIndex $=0 \&$ doclang $=E N \&$ mode $=1$ st $\&$ dir $=\&$ occ $=$ first $\&$ part $=1 \&$ cid $=5243153$ (14. veljače 2019.). Više o tome u: First, H., Trade secrets and antitrust law, u: Dreyfuss, op. cit., str. 360-363 i Turner, J., C., Intellectual Property and EU Competition Law, Oxford, Oxford University Press, 2010., str. 19. Također je izrijekom propisano u članku 7. Direktive 2016/943 kako se mjere, postupci i pravna sredstva propisani tom Direktivom moraju primjenjivati na način kojim se izbjegava stvaranje prepreka za zakonitu trgovinu na unutarnjem tržištu.

51 Meitinger, op. cit., str. 3.

52 Iz Procjene učinka Prijedloga direktive, (bilješka 12), str. 19-20.

53 Odredbe o zaštiti poslovne tajne u okviru Sporazuma TRIPS važne su jer države obvezuje pružati zaštitu poslovnim tajnama, no razina harmonizacije nije dostatna s obzirom na vrlo široko postavljenu obvezu i različite mogućnosti implementacije u propisima država članica. Nema naznaka da bi se na međunarodnom planu u okviru multilateralnih organizacija (WIPO, 
Zbog toga je donesena Direktiva EU 2016/943, ${ }^{54}$ odnosno kako bi se na razini Europske unije ujednačila pravna zaštita poslovnih tajni, odnosno uspostavila „dostatna i dosljedna razina pravne zaštite u okviru građanskog prava na unutarnjem tržištu u slučaju nezakonitog pribavljanja, korištenje ili otkrivanja poslovne tajne“ (točka 10. preambule Direktive EU 2016/943). Detaljno je određen opseg zaštite poslovnih tajni time što je u članku 4. propisano kada se pribavljanje, korištenje ili otkrivanje poslovne tajne smatra nezakonitim ${ }^{55}$ dok se u članku 3. navodi što se smatra zakonitim pribavljanjem, korištenjem i otkrivanjem poslovnih tajni.

Tako je dopušteno neovisno otkriti ili stvoriti sadržaj zaštićen poslovnom tajnom. Trećima je dopušteno da ih otkriju opažanjem, proučavanjem, rastavljanjem ili testiranjem proizvoda ili predmeta učinjenih dostupnim javnosti što se naziva reverzibilnim inženjeringom. Ovo zbog toga što poslovne tajne nisu isključivo pravo pa trećima nije zabranjeno da dođu do takvih podataka i informacija na bilo koji način, sve dok se s obzirom na te okolnosti može smatrati poštenom poslovnom praksom. Zakonitim se smatra i pribavljanje poslovne tajne ostvarivanjem prava radnika ili predstavnika radnika na informiranje i savjetovanje te ako se dopušta ili zahtijeva posebnim propisima.

Opseg zaštite prava uz to se ograničava propisivanjem iznimka u primjeni mjera, postupaka i pravnih sredstava predviđenih Direktivom. Ta su ograničenja sadržana u

WTO) radilo na daljnjoj harmonizaciji ovog područja. Ipak u odnosima između država posebno u okviru pregovora o bilateralnim trgovinskim odnosima uočava se sve veća potreba uspostave koherentne zaštite poslovnih tajni. Tako je ovo područje trebalo biti uređeno i trgovinskim sporazumom između Europske unije i Sjedinjenih Američkih Država, tzv. Transatlantskim trgovinskim i investicijskim partnerstvom (TTIP). Prema Bux, U., Trade secrets, In-depth analysis: document requested by the URI Committee, Europski parlament, PE 493.055, Brussels, travanj 2014., str. 9. i 11., dostupno na: http://www.europarl.europa.eu/RegData/etudes/note/ join/2014/493055/IPOL-JURI_NT(2014)493055_EN.pdf (18. veljače 2019.). Bez obzira na trenutni zastoj pregovora oko TTIP-a znakovito je da su Direktiva EU 2016/943 i američki propis kojim se na federalnoj razini u SAD-u uređuje građanskopravna zaštita poslovnih tajni (Defend Trade Secrets Act, 18 U.S.C. §1836, dostupno na: https://www.govinfo.gov/content/ pkg/PLAW-114publ153/html/PLAW-114publ153.htm (18. veljače 2019.)) doneseni u jeku intenzivnih pregovora oko TTIP i to u gotovo isto vrijeme - Direktiva je usvojena 8. lipnja 2016., a američki zakon 11. svibnja 2016. godine.

54 Iz obrazloženja Prijedloga Direktive, (bilješka 8), str. 7.

55 Pribavljanje poslovne tajne bez pristanka nositelja poslovne tajne smatra se nezakonitim kada je ono učinjeno neovlaštenim pristupom, prisvajanjem ili umnožavanjem bilo kojih dokumenata, predmeta, materijala, tvari ili elektroničkih spisa ili bilo kojeg drugog ponašanja koje se u tim okolnostima smatra protivnim poštenim poslovnim praksama. Nadalje, korištenje ili otkrivanje poslovne tajne smatra se nezakonitim kada ga bez pristanka nositelja poslovne tajne učini osoba koja je pribavila je poslovnu tajnu nezakonito, ili krši sporazum o povjerljivosti, ili bilo koju drugu obvezu neotkrivanja poslovne tajne, ili pak krši ugovornu ili bilo koju drugu obvezu kojom se ograničava korištenje poslovne tajne. Nezakonito je i kada je osoba znala, ili je u tim okolnostima trebala znati, da je poslovna tajna pribavljena izravno ili neizravno od druge osobe koja je nezakonito koristila, ili otkrila poslovnu tajnu. Nezakonitim korištenjem poslovne tajne smatraju se i proizvodnja, stavljanje u ponudu, ili stavljanje na tržište robe kojom je počinjena povreda odnosno uvoz, izvoz ili skladištenje robe kojom je počinjena povreda u te svrhe, ako je osoba koja je provodila takve aktivnosti znala ili je u tim okolnostima trebala znati da je poslovna tajna korištena nezakonito. 
članku 5. Direktive 2016/943. Ovaj je članak bio sporan u procesu donošenja Direktive tijekom političkih pregovora Vijeća i Europskog parlamenta te je izazvao velike polemike i zanimanje javnosti. ${ }^{56}$ Predviđene se iznimke odnose na ostvarivanje prava na slobodu izražavanja misli, prava na pristup informacijama te slobode izvještavanja, zaštitu prijavitelja nepravilnosti (tzv. zviždača) otkrivanje od strane radnika svojim predstavnicima te u svrhu zaštite drugih legitimnih interesa sukladno propisima. To su slučajevi koji će se moći istaknuti kao obrana u sporu zbog povrede poslovne tajne te su svojevrsno jamstvo da zaštita poslovnih tajni neće neopravdano ograničiti slobodu izvještavanja i izražavanja misli, pravo na pristup informacijama, rad sindikata te prijavljivanje nepravilnosti koji kao takvi imaju širi pozitivni učinak na društvo. Ipak ostaje za vidjeti kako će sudovi primjenjivati ove odredbe. ${ }^{57}$ Kao istaknuta opasnost je i činjenica da sama opasnost da osobe koje se ovim odredbama želi zaštititi budu tužene većinu njih može obeshrabriti i odvratiti od bilo kakvog djelovanja i aktivnosti u tom smjeru, makar i bili zaštićeni iznimkama. ${ }^{58}$

Odredbe Direktive zasigurno razrađuju osnovne postavke zaštite propisane Sporazumom TRIPS, no analiza sadržaja spomenutih članaka 3. i 4. pokazuje da samo razgraničenje zakonitog od nezakonitog postupanja u vezi s poslovnim tajnama i dalje počiva na utvrđenju je li pribavljanje, korištenje i otkrivanje bilo u skladu ili protivno poštenim poslovnim praksama. Utoliko se može postaviti pitanje donosi li Direktiva 2016/943 uistinu nešto novo u odnosu na odredbe Sporazuma TRIPS. Neosporan je doprinos Direktive u propisivanju mjera, postupaka i pravnih sredstava u slučaju povrede poslovne tajne, ${ }^{59}$ no s obzirom na opseg zaštite, definiciju i utvrđivanje

56 U dijelu javnosti Direktiva je shvaćena kao pokušaj velikih kompanija da zaštitom poslovnih tajni i ovom Direktivom spriječe javni nadzor korporacija u cilju zaštite javnog interesa. Posebno su nevladine udruge izražavale bojazan da će Direktiva biti korištena kako bi se spriječilo otkrivanje u javnom interesu podataka o sigurnosti proizvoda, kao što su rezultati kliničkih ispitivanja lijekova ili toksikološke studije pesticida. Tako i Corporate Europe Observatory (CEO), Adapting the EU Directive on Trade Secrets „Protection“ into National Law - A transposition guide for legislators and civil society organisations, veljača 2017., str. 3. - 8., dostupno na: https://corporateeurope.org/sites/default/files/attachments/trade_secrets protection_directive_-_a_transposition_briefing.pdf (25. veljače 2019.).

57 Dodatno valja napomenuti da u trenutku usvajanja Zakona o zaštiti neobjavljenih informacija s tržišnom vrijednosti nije postojalo propis kojim su se štitili „Zviždači“. Zakon o zaštiti prijavitelja nepravilnosti (NN, br. 17/19.) donesen je 20. veljače 2019. godine. Odredba članka 8. točke 2. Zakona o zaštiti neobjavljenih informacija $\mathrm{s}$ tržišnom vrijednosti trebala bi se primjenjivati sukladno odredbama tog zakona. U tom kontekstu, a i slijedom odgovarajuće odredbe članka 5. Direktive 2016/943 trebalo bi uzeti da se iznimka odnosi na otkrivanje propusta, nepravilnosti i nezakonite aktivnosti. Pojam wrongdoing preveden je u hrvatskoj verziji Direktive kao „prijestup“, pa je slijedom toga pojam prijestup korišten i u Zakonu, no sukladno Zakonu o zaštiti prijavitelja nepravilnosti zaštita obuhvaća svaki oblik nepravilnosti, ne samo nezakoniti (što bi se moglo smatrati prijestupom), već i nepravilnosti koje ne proizlaze samo iz kršenja zakona ili drugih propisa.

58 CEO, (bilješka 56), str. 20.

59 Važnost Direktive stoga se očituje ponajprije u građansko-procesnim aspektima zaštite poslovne tajne koje donosi. Tomu u prilog ide i činjenica da veći dio odredbi Direktive sadrži pravila građanskog postupka, odnosno mjere, postupke i pravna sredstva koje stoje na raspolaganju nositeljima prava u slučaju tužbe zbog povrede poslovne tajne. Jedan je od ciljeva donošenja Direktive prema točki 24. Preambule, osigurati zaštitu povjerljivosti poslovne tajne, koja je 
postojanja povrede, ne donosi bitan pomak. Tumačenje pojma poštenih poslovnih praksa i time razgraničenje zakonitog i nezakonitog postupanja u svezi s povredama poslovnih tajni ostaje stoga na sudovima.

\section{VAŽNOST POSLOVNIH TAJNI U POSLOVANJU}

Poduzeća stalno ulažu u pribavljanje, razvoj i primjenu znanja i iskustva te informacija. To ulaganje utječe na njihovu konkurentnost i uspješnost inovacija na tržištu, čime se osigurava povrat ulaganja što je u svojoj biti temeljna motivacija za poslovna istraživanja i razvoj. Poslovna tajna tako postaje alat za poslovnu konkurentnost i upravljanje istraživačkim inovacijama te utječe na povećanje vrijednosti poduzeća. Procjena ekonomske vrijednosti poslovnih tajni zahtjevna je upravo zbog uvjeta držanja u tajnosti tih informacija, ${ }^{60}$ iako postoje određene naznake njihove vrijednosti, koje se prije svega odnose na podatke o procjeni visine naknade štete u sporovima zbog povrede poslovnih tajni. Takvi podatci ukazuju na znatne iznose. Studije ukazuju i da postoji pozitivna i statistički važna poveznica između poslovnih tajni i pokazatelja inovativnosti poslovanja.$^{61}$ Dodatno istraživanja pokazuju da kompanije same ocjenjuju poslovne tajne kao strateški važan instrument rasta, konkurentnosti i inovativnosti svoga poslovanja. ${ }^{62}$

Pri donošenju Direktive EU 2016/943 upravo su ti razlozi isticani kao argumenti u prilog normativnog uređenja zaštite poslovnih tajni na razini Europske unije. Navodi se i da poduzeća neovisno o veličini pridaju barem jednaku važnost poslovnim tajnama kao i ostalim oblicima intelektualnog vlasništva. ${ }^{63}$

Kod usporedbe značaja poslovnih tajni sa značajem formalnih prava intelektualnog vlasništva treba sagledati koje su prednosti, a koji nedostatci svakog od tih oblika zaštite, jer će često njihova primjena ovisiti o određenim karakteristikama svakog od njih. Prema osnovnim karakteristikama, prava intelektualnog vlasništva bitno su različita od poslovnih tajni, utoliko što su vremenski ograničena isključiva prava koja se stječu na zakonski propisani način. S tim da se prava industrijskog vlasništva u pravilu stječu priznanjem u postupku registracije pred nadležnim tijelima u svrhu upisa u javne upisnike uz javnu objavu sadržaja zaštite trećima.

Dodatno pri usporedbi treba uzeti u obzir da svaki oblik intelektualnog vlasništva

predmet spora, jer se pokazalo da mogućnost gubitka povjerljivosti tijekom sudskoga postupka često odvraća zakonite nositelje od pokretanja tužbi za zaštitu poslovnih tajni.

60 OECD, Enquiries Into Intellectual Property's Economic Impact, 2015., str. 36. Dostupno na: http://www.oecd.org/sti/ieconomy/intellectual-property-economic-impact.htm (18. veljače 2019.).

61 ibid., str. 11.

62 To pokazuju rezultati javnog savjetovanja koje je Europska komisija provela od 11. prosinca 2012. do 8. ožujka 2013. godine, prema Radnom dokumentu Komisije (bilješka 12), str. 80 -99. Čak $91 \%$ kompanija koje su sudjelovale smatra poslovne tajne važnim instrumentom poslovanja. Studija Intelektualno vlasništvo (IV) i rezultati malih i srednjih poduzeća za 2016. godinu (bilješka 1), pokazuje da većina ispitanika iz reda, tzv. malog i srednjeg poduzetništva svoje poslovanje smatra inovativnim, a kao najvažnije oblike zaštite svojih inovacija na drugom mjestu navode poslovnu tajnu (42\%).

63 Iz obrazloženja Prijedloga Direktive, (bilješka 8), str. 3. 
ima određen predmet zaštite pa ovisno o tome poslovne tajne s nekim oblicima intelektualnog vlasništva imaju manje ili važnije sličnosti predmeta zaštite, a otuda i konkurentnu primjenu. Izum koji se može odnositi na novi inventivni proizvod ili proizvodni postupak kao i na novu primjenu postojećih proizvoda ili postupaka bit je tehnološke inovacije i moguće ga je zaštititi patentom, kao oblikom intelektualnog vlasništva. No, po prirodi stvari takve tehnološke inovacije alternativno se mogu štiti i kao poslovne tajne.

U kontekstu patentne zaštite u postupku za priznanje patenta potrebno je otkriti tehničke detalje izuma u opsegu koji omogućuje stručnjaku iz predmetnog područja izradu ili upotrebu izuma. Takav je postupak često vrlo kompliciran i skup, te pretpostavlja otkrivanje predmeta izuma koji nakon perioda važenja prava, što ne može biti dulje od 20 godina, postaje javno dostupan svima. S aspekta trajanja, prednost se može dati poslovnim tajnama jer njihovo trajanje nije vremenski ograničeno, pa se u njihovu zaštitu može pouzdati potencijalno neograničeno, sve dok se one drže u tajnosti. Činjenica što zaštita ne pretpostavlja otkrivanje također se može smatrati prednošću jer se drugima ne otkriva unaprijed sadržaj informacije koji se štiti. No s druge strane, opseg je zaštite patentom šire jer pravo djeluje erga omnes. Neovisno otkrivanje poslovne tajne ili reverzibilni inženjering realna je opasnost gubitka stvarnog monopola nad informacijama koji se štite poslovnom tajnom u bilo kojem trenutku. Štoviše, osoba koja je neovisno došla do takvih izuma može se odlučiti na njihovu zaštitu patentom što će nositelja poslovne tajne dovesti u poziciju da bude isključen od njegova daljnjeg korištenja. S obzirom na opasnost od reverzibilnog inženjeringa, one inovacije koje su očite, odnosno one za koje se mogu rekonstruirati tehnički detalji izuma uvidom u proizvod ili postupak koji se temelji na izumu, nisu pogodne za zaštitu poslovnom tajnom. S druge strane, netehnološke inovacije ${ }^{64}$ često nisu patentibilne, pa će jedina opcija preostati zaštita u okviru poslovnih tajni. Činjenica što je postupak registracije patenta kompliciran i skup, često se smatra prednošću na strani zaštite poslovnom tajnom kod kojih zaštita ne pretpostavlja provođenje postupka registracije. ${ }^{65}$ Međutim, treba uzeti u obzir da i nositelj poslovne tajne mora računati na troškove poduzimanja zaštitnih mjera za čuvanje tajnosti, a nužno je napomenuti da je dokazivanje povrede poslovne tajne pred sudom s obzirom na to da se ne radi o registriranom pravu vrlo često skupo i teško.

Provedena istraživanja preferirane strategije zaštite inovativnog poslovanja pokazuju da inovativna poduzeća često koriste kombinaciju zaštite poslovnom

64 Takve su inovacije koje se očituju u korištenju i primjeni raznolikog raspona strateških poslovnih informacija, tzv. „meke“ inovacije karakteristične za uslužni sektor koji ne ovisi toliko o tehnološkim procesima i inovacijama proizvoda. Poslovne tajne, stoga su iznimno važne za taj ključni dio gospodarstva EU-a, prema obrazloženju Prijedloga Direktive, (bilješka 8), str. 3. Netehnološke inovacije obuhvaćale bi i književne, umjetničke i znanstvene inovacije koje još nisu dobile svoj izražaj. Autorskim se pravom ne štiti ideja, nego autorsko djelo koje je izražaj ideje, a tijekom nastajanja autorskog djela, dok je djelo tek u fazi ideje, takvu ideju bilo bi moguće zaštititi poslovnom tajnom. Tako i Cornish, op. cit., str. 306.

65 Zbog toga se sukladno obrazloženju Prijedloga Direktive, (bilješka 8) smatra da su poslovne tajne osobito važne za mala i srednja poduzeća i novoosnovana poduzeća. 
tajnom i patentom, posebno kod zaštite složenih inovacija. ${ }^{66}$ Pritom se ne misli na kumulativnu zaštitu jer ova dva oblika zaštite međusobno isključuju jedan drugo. Patent pretpostavlja otkrivanje pa ne može istovremeno biti i poslovna tajna. No, s primjenom izuma koji je patentiran mogu dodatno biti povezana određena tehnološka znanja i iskustvo ${ }^{67}$ koje će se komplementarno štititi kao poslovna tajna. Pored svega treba istaknuti i značaj poslovnih tajni za zaštitu svih vrsta inovacije u ranom stadiju njihovoga razvoja. ${ }^{68}$ U konačnici svako pravo intelektualnog vlasništva nužno počinje s tajnom. ${ }^{69}$

Pritom valja biti oprezan kod naglašavanja značaja poslovnih tajni za inovativnost. Naime, inovacija pretpostavlja određenu novost. Poslovna tajna ne mora nužno biti objektivno odnosno univerzalno nova. Tako će se baze podataka, kao što su primjerice popisi klijenta također smatrati poslovnim tajnama, iako pritom sadržaj tih podataka čine elementi koji nisu tajni, već način na koji su te baze sastavljene. Informacija mora biti tajna u smislu da nije općenito poznata ili lako dostupna osobama iz krugova koji se obično bave predmetnom vrstom informacija, a ne nužno nova.

Sustav zaštite prava intelektualnog vlasništva počiva na premisi da se priznanjem isključivih prava kroz određeno razdoblje nakon kojeg zaštićeni sadržaj postaje javno dostupan i slobodan za korištenje, potiče inovativnost i gospodarski napredak društva u cjelini. Čuvanjem informacija u tajnosti čini se upravno suprotno pa se postavlja pitanje zašto bi se pružala zaštita poslovnim tajnama, odnosno ohrabrivala inovativnost koja ostaje u sferi tajnosti umjesto da se potiče njihovo otkrivanje koje će generirati stjecanje novih znanja i napredak. ${ }^{70}$ Premda to može izgledati na prvi pogled paradoksalno, smatra se da zaštita poslovnih tajni u stvari potiče njihovo otkrivanje. ${ }^{71}$

66 Studija „Zaštita inovacija putem poslovnih tajni i patenata: odrednice za poduzeća u Europskoj uniji“, koju je objavila Europska promatračnica za povrede prava intelektualnog vlasništva pri Uredu Europske unije za intelektualno vlasništvo (EUIPO), dostupno na: http://www.stopkrivotvorinama-i-piratstvu.hr/files/file/pdf/studije/EUIPO_zastita_inovacija_poslovne_tajne_ patenti.pdf (20. veljače 2019.).

67 Cornish, op. cit., str. 301. Patentom će se zaštititi centralni dio samog izuma, dok će većina informacija do kojih se došlo pri uvođenju predmeta izuma u industrijsku proizvodnju za komercijalnu uporabu ostati u domeni poslovne tajne. Pritom treba voditi računa da u postupku za priznanje patenta postoji obveza otkrivanja tehničkih detalja izuma u opsegu koji omogućuje stručnjaku iz predmetnog područja izradu ili upotrebu izuma.

68 Pisci ne otkrivaju priču na kojoj rade (buduće autorsko pravo), proizvođači automobila ne prosljeđuju prve nacrte novoga modela (budući dizajn), poduzeća ne otkrivaju preliminarne rezultate tehnoloških eksperimenata (budući patent), poduzeća zadržavaju za sebe informacije koje se odnose na lansiranje nove marke proizvoda (budući žig) itd. Iz obrazloženja Prijedloga Direktive, (bilješka 8), str. 2.

69 Čak i kada se odluči na zaštitu patentom u fazi istraživanja i pisanja patentne prijave do trenutka podnošenja patentne prijave, nositelj se mora pouzdati u zaštitu poslovne tajne.

70 Iako se širenje znanja smatra poželjnim društvenim učinkom, jer omogućava daljnje inovacije i napredak, u kontekstu poslovnih tajni može imati i negativni učinak. Iz studije OECD-a (bilješka 54), str. 54, kao primjer se navodi otkrivanje punog algoritma pretraživača koji koristi Google. Njegovo otkrivanje ne bi naštetilo samo nositelju već i društvu u cjelini jer bi se znajući način na koji se pretražuje i rangira rezultate pretraživanja s njima moglo manipulirati pa bi u konačnici rezultati postali iskrivljeni i nepouzdani.

71 Lemley, M., A, The surprising virtues of treating trade secrets as IP rights, u: Dreyfuss, op. cit., 
Naime, nositelji poslovnih tajni umjesto poduzimanja mjera potpune zaštite tajnosti pouzdavši se u njihovu pravnu zaštitu upuštati će se u otkrivanje takvih podataka poslovnim parterima radi ostvarivanja zajedničke suradnje. Time zaštita poslovnih tajni povećava i vjerojatnost prelijevanja znanja. ${ }^{72}$ Stoga poslovne tajne s obzirom na suvremene načine dolaska do inovacija suradnjom i veću zastupljenost inovacija koje se očituju u postupnim poboljšanjima u odnosu na radikalne inovacije imaju sve veću važnost. $^{73}$

\section{IMPLEMENTACIJA U NACIONALNO ZAKONODAVSTVO - ZAKON O ZAS̆TITI NEOBJAVLJENIH INFORMACIJA S TRŽIŠNOM VRIJEDNOSTI}

Države članice Europske unije bile su dužne prenijeti odredbe Direktive 2016/943 u svoje nacionalno zakonodavstvo do 9. lipnja 2018. godine. Pritom države članice samostalno izabiru oblik i metodu kojom će to učiniti. Izbor ovisi ponajprije o postojećim propisima u području i nacionalnom pravnom sustavu u cjelini u koji se implementirani zakon, podzakonski akt i sl. treba što bolje uklopiti, a da se pritom nužno osigura postizanje cilja zadanoga Direktivom.

\subsection{Donošenje novog zakona}

Pri odluci o načinu transponiranja obveza iz Direktive trebalo je voditi računa o činjenici da u hrvatskom pravnom sustavu postoji cijeli niz propisa koji djelomično uređuju područje zaštite poslovne tajne ili propisuju načine ophođenja s poslovnim tajnama u određenim građanskim ili upravnim postupcima. Međutim, većina se tih propisa odnosi na povjerljive poslovne informacije u širem smislu, a ne na poslovne tajne u smislu koji odgovara obliku intelektualnog vlasništva iz Direktive 2016/943 ili sadrže odredbe vezane za zaštitu ili korištenje poslovne tajne ili povjerljivih informacija u posebnim postupcima pa transpozicijom Direktive u okviru tih propisa ne bi bio postignut njezin zadani cilj.

Primjerice, u pogledu propisivanja pojma tajnosti te određenih mjera i postupaka za utvrđivanje, uporabu i zaštitu poslovne i profesionalne tajne na snazi su odredbe odgovarajućih glava (VIII. i IX.) Zakona o zaštiti tajnosti podataka. ${ }^{74}$

str. 110 .

72 Iz studije OECD-a, (bilješka 60), str. 15.

73 Brant, J., Lohse, S., Trade secrets: Tools for innovation and collaboration, ICC Innovation and Intellectual Property Research Paper, 2014, br. 3., str. 12., dostupno na: https://cdn.iccwbo.org/ content/uploads/sites/3/2017/02/ICC-Research-Trade-Secrets-english.pdf (18. veljače 2019.).

74 Zakon o zaštiti tajnosti podataka (NN, br. 108/96.) prestao je važiti stupanjem na snagu Zakona o tajnosti podataka (NN, br. 79/07. i 86/12.) osim odredaba glave 8. i 9. kojima se uređuju poslovna i profesionalna tajna. Peran, B, Goreta, M., Vukošić, K., Pojam i vrste tajni, Zbornik radova Veleučilišta u Šibeniku, 3-4/2015, str. 132 navode kako je razlog donošenja Zakona o tajnosti podataka to što su se načela tajnosti trebala uskladiti sa suvremenim standardima tajnosti podataka zemalja Europske unije i NATO-a. Nejasno je međutim zašto pri donošenju toga zakona nije riješeno pitanje daljnje sudbine poslovnih i profesionalnih tajni koje novim zakonom nisu obuhvaćene, ali nisu niti ukinute. Svakako prestanak važenja zakona uz ostavljanje 
Definicija poslovne tajne sadržana u tim odredbama odnosi se na poslovnu tajnu čiji je nositelj pravna osoba, obuhvaća povjerljive poslovne informacije u širem smislu i ne propisuje nikakve pravne mjere za njihovu zaštitu. Stoga Direktivu nije bilo moguće transponirati ispravno u okviru tih odredbi, ali se opravdano postavlja pitanje jesu li donošenjem Zakona o zaštiti neobjavljenih informacija s tržišnom vrijednosti te odredbe trebale prestati važiti. ${ }^{75}$ Razlog što Zakon o zaštiti neobjavljenih informacija $\mathrm{s}$ tržišnom vrijednosti nije mijenjao niti ukidao ove odredbe leži upravo u činjenici što je definicija poslovnih tajni iz njega uža od onih obuhvaćenim glavom VIII. i odnosi se samo na poslovne tajne kao oblik intelektualnog vlasništva, a slijedom zahtjeva Direktive. Ukidanjem odredbi glave VIII. izostalo bi bilo kakvo pravno uređenje poslovnih tajni u širem smislu. Jednako tako ne bi bilo opravdano poslovne tajne u širem obuhvatiti odredbama zakona kojim se implementira Direktiva 2016/943, jer bi im se time pružila preširoka zaštita koju zaslužuju samo one poslovne tajne koje imaju komercijalnu vrijednosti i jedan su od oblika intelektualnog vlasništva. Pri implementaciji Direktive u pravni sustav Republike Hrvatske ne zadire se, stoga u odredbe Glave VIII. koje i dalje nastavljaju važiti. No, zbog toga se u nazivu zakona za razliku od Direktive ne govori o poslovnim tajnama. ${ }^{76}$

Vezano za zaštitu poslovnih tajni u okviru građanskog prava sukladno Zakonu o obveznim odnosima $^{77}$ ona se ostvaruje i kao zaštita prava osobnosti pravne osobe. $\mathrm{O}$ tom kontekstu zaštite poslovnih tajni kao osobnih, neimovinskih prava, već je ranije u tekstu bilo riječi. Zaštita se ovdje očituje prvenstveno u naknadi neimovinske štete te je kumulativna zaštiti slijedom Zakona o zaštiti neobjavljenih informacija s tržišnom vrijednosti primjenom kojeg se pruža zaštita koja se očituje u naknadi prvenstveno imovinske štete.

Zaštita predviđena u okviru Zakona o $\operatorname{trgovini}^{78}$ gdje se jednom od radnji koje se smatraju nepoštenim trgovanjem smatra i protupravno pribavljanje poslovne tajne drugog trgovca ili bespravno iskorištavanje povjerene poslovne tajne drugog trgovca po uzoru na odredbe Sporazuma TRIPS zaštitu poslovnih tajni svrstava se u okvir nepoštenog trgovanja. Međutim ove su odredbe podnormirane u pogledu definicije poslovne tajne prema odredbama Sporazuma TRIPS. ${ }^{79}$ Osim toga, Direktiva 2016/943 sadrži materijalne i postupne odredbe vezane uz zaštitu poslovnih tajni stoga se u

na snazi pojedinih njegovih odredba ne doprinosi pravnoj sigurnosti i vrlo je negativna praksa.

75 Tim više što se radi o odredbama izdvojenim iz zakona koji je prestao važiti kako je prethodno opisano. No, tada bi se i dalje trebalo riješiti pitanje uređenja profesionalne tajne (glava IX.).

76 U odnosu na naziv zakona upućen u zakonodavnu proceduru u prvom čitanju koji je pratio naziv Direktive, osim korištenja zajedničkoga pojma ,poslovne tajne“, konačni naziv zakona, Zakon o zaštiti neobjavljenih informacija s tržišnom vrijednosti posljedica je traženja da se sam naziv prilagodi duhu hrvatskoga jezika, prema Izvješću Odbora za obrazovanje, znanost i kulturu P.Z.E., br. 225, dostupno na: http://www.sabor.hr/radna-tijela/odbori-i-povjerenstva/ izvjesce-odbora-za-obrazovanje-znanost-i-kulturu-o-147 (14. veljače 2019.).

77 Zakon o obveznim odnosima (NN, br. 35/05., 41/08., 125/11., 78/15. i 29/18.).

78 Zakon o trgovini (NN, br. 87/08., 116/08., 76/09., 114/11., 68/13. i 30/14.).

79 Republika Hrvatska članica je WTO-a od 30. studenog 2000. godine, pa je od tada obvezna primjenjivati odredbe Sporazuma TRIPS. Nije poznato je li u sudskim sporovima zbog povrede poslovne tajne doista primijenjena definicija poslovne tajne iz ovog za Republiku Hrvatsku obvezujućega međunarodnog ugovora. 
dijelu koji se tiče postupovnih odredbi nije mogla implementirati u okviru Zakona o trgovini. Teoretski je bilo moguće postupovne odredbe transponirati u okviru općeg propisa kojim je uređen građanski postupak, uz razradu materijalnih normi u okviru Zakona o trgovini. Međutim, donošenje posebnog zakona izvan okvira zaštite nepoštenog trgovanja u skladu je s načinom uređenja predmetne materije $u$ Direktivi 2016/943 kojom se detaljno uređuju mjere protiv nezakonitog pribavljanja, uporabe i odavanja poslovnih tajni koje imaju gospodarsku vrijednost kao specifičnog oblika intelektualnog vlasništva. Osim toga, teži se izbjegavati da se odredbe općih propisa, konkretno općeg propisa kojim se uređuje parnični postupak, opterećuju propisivanjem određenih specifičnih postupanja za određenu vrstu sporova.

Zbog tih je razloga cjelovito pravno uređenje poslovnih tajni kao oblika intelektualnog vlasništva uz propisivanje posebnosti građanskog postupka u slučaju njihove povrede bio ispravan način da se osigura postizanje cilja zadanoga Direktivom2016/943.

Pritom valja naglasiti da Direktiva 2016/943 ne utječe na obvezu otkrivanja poslovnih tajni zbog javnog interesa tijelima javne vlasti ili upravnim ili sudskim tijelima radi obavljanja njihovih dužnosti kao ni na načine postupanja tijela javne vlasti s poslovnim tajnama kada se po posebnim propisima od njih zahtijeva ili im se dopušta da te informacije otkrivaju (članak 1. stavak 2.), pa ovo nije bio predmet usklađivanja niti je obuhvaćeno Zakonom o zaštiti neobjavljenih informacija s tržišnom vrijednosti. ${ }^{80}$

Osim toga, Direktiva se ograničava na harmonizaciju zaštite u okviru građanskog prava (članka 6. stavak 1.), dok kaznena odgovornost za povrede poslovnih tajni nije usklađena na razini Europske unije, a u Republici je Hrvatskoj predmet uređenja Kaznenog zakona. ${ }^{81}$

\subsection{Primjena Direktive o provedbi prava}

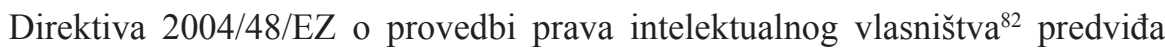
mjere, postupke i pravna sredstva za provedbu prava intelektualnog vlasništva $\mathrm{u}$ građanskim postupcima. Horizontalno zahvaća u pravila o građanskim postupcima za zaštitu prava u slučaju povrede, za razliku od većine direktiva iz područja prava intelektualnog vlasništva koje mahom zahvaćaju materijalnopravne sustave prava

80 Stoga će odredbe vezane za zaštitu ili korištenje poslovne tajne (u pravilu i šire od toga, odnosit će se na sve povjerljive podatke koji ne moraju nužno biti poslovne tajne) u pojedinim posebnim postupcima $i$ dalje biti sadržane u nizu propisa kojim se uređuju ti postupci (primjerice postupanje s tajnim podatcima prema članku 52. Zakona o javnoj nabavi (NN, br. 120/16.), postupanje s povjerljivim podatcima prema članku 7. Zakona o postupcima naknade štete zbog povreda prava tržišnog natjecanja (NN, br. 69/17.). Obvezu otkrivanja poslovnih tajni zbog javnog interesa nalazimo, primjerice u Zakonu o pravu na pristup informacijama (NN, br. 25/13. i 85/15.) koja se utvrđuje provođenjem testa razmjernosti i javnog interesa.

81 Kaznenim zakonom (NN, br. 125/11., 144/12., 56/15., 61/15., 101/17. i 118/18.) predviđeno je kazneno djelo odavanja i neovlaštenog pribavljanja poslovne tajne (članak 262.).

82 Direktiva 2004/48/EZ Europskog parlamenta i Vijeća od 29. travnja 2004. o provedbi prava intelektualnog vlasništva, SL L 157, 30.4.2004., str. 45-86. 
intelektualnog vlasništva. ${ }^{83}$ Direktiva o provedbi prava ne definira pojam prava intelektualnog vlasništva, odnosno ne sadržava popis konkretnih prava koja se smatraju pravima intelektualnog vlasništva za njezine potrebe. No, u točki 13. preambule objašnjava se da bi se njezino područje primjene trebalo odrediti što je šire moguće kako bi obuhvatilo sva prava intelektualnog vlasništva. ${ }^{84}$ Zaštita poslovnih tajni nije isključivo pravo intelektualnog vlasništva, pa tako ne bi bila izravno obuhvaćena opsegom primjene ove direktive. ${ }^{85}$ Ipak se navodi da su države članice slobodne proširiti u svojim nacionalnim pravnim sustavima primjenu odredba direktive i na nepošteno trgovanje, uključujući parazitske kopije i slične aktivnosti.

Direktiva 2016/943 sadrži niz odredaba koje se odnose na građanskopravnu zaštitu poslovnih tajni. Prema točki 39. preambule ako se njezino područje primjene preklapa s područjem primjene bilo kojih drugih relevantnih propisa, trebala bi se smatrati lex specialis. Tako se Direktiva 2016/943 ima smatrati lex specialis i u slučaju preklapanja s područjem primjene Direktive o provedbi prava u slučaju da države članice odluče proširiti odredbe Direktive o provedbi prava i na poslovne tajne, iako to nisu obvezatne učiniti. ${ }^{86}$

Pri prenošenju odredbi Direktive 2016/943 u nacionalno zakonodavstvo Republike Hrvatske donošenjem Zakona o zaštiti neobjavljenih informacija s tržišnom vrijednosti, proširena je primjena Direktive o provedbi prava i na poslovne tajne na nacionalnoj razini u skladu s točkom 13. preambule Direktive. Stoga u slučaju nezakonitog pribavljanja, korištenja ili otkrivanja poslovnih tajni, nositelj može ostvariti korist u prvom redu od mjera, postupaka i pravnih sredstava iz Direktive 2016/943, ali i od onih mjera, postupaka i pravnih sredstava iz Direktive o provedbi prava koje se ne preklapaju s onima iz Direktive 2016/943. Tako su u Zakonu sadržane i mjere za pribavljanje dokaza (članak 17.), mjere osiguranja dokaza (članak 20.) i pravo na dobivanje podataka (članak 16.) kako to propisuju odredbe Direktive o provedbi prava. Odredbe koje bi uređivale ove mjere i sredstva nisu sadržane u Direktivi 2016/943 pa one nisu bile predmet usklađenja s tom Direktivom i mogle su

83 Matanovac, R., Građanskopravna zaštita prava intelektualnog vlasništva u odnosu prema Direktivi 2004/48/EZ o provedbi prava intelektualnog vlasništva - analiza stanja i nagovještaj promjena, u: Matanovac, R. (ur.), Hrvatsko pravo intelektualnog vlasništva u svjetlu pristupa Europskoj uniji, Zagreb, Narodne novine/Državni zavod za intelektualno vlasništvo, 2006., str. 122.

84 Izjava Komisije o članku 2. Direktive 2004/48/EZ Europskog parlamenta i Vijeća o provedbi prava intelektualnog vlasništva (2005/295/EZ), SL L 94, 13.4.2005., str. 37. Izdana je kako bi se bolje odredilo njezino područje primjene. Izjava je pravno neobvezujuća. Prema Izjavi, Komisija smatra da su najmanje sljedeća prava intelektualnog vlasništva obuhvaćena njezinim područjem primjene: autorska prava i srodna prava, pravo sui generis proizvođača baze podataka, pravo stvaratelja topografija za poluvodičke proizvode, prava na žig, prava na dizajn, patentna prava, uključujući prava koja proizlaze iz svjedodžaba o dodatnoj zaštiti, oznake zemljopisnog podrijetla, prava iz korisnih modela, prava zaštite biljnih sorti, trgovačka imena, ako su u predmetnom nacionalnom pravu zaštićena kao isključiva prava vlasništva.

85 Tako i Montagnon, R., The Trade Secrets Directive: consistency of approach required, with or without Brexit, Journal of Intellectual Property Law and Practice, vol. 11, 9. rujan 2016., str. 644, dostupno na: https://doi.org/10.1093/jiplp/jpw122 (25. veljače 2019.).

86 Tako i u Smjernicama o određenim aspektima Direktive 2004/48/EZ Europskog parlamenta i Vijeća o provedbi prava intelektualnog vlasništva COM/2017/0708 od 29.11.2017., str. 23. 
biti i izostavljene iz zakona da se nije proširila primjena Direktive o provedbi prava i na poslovne tajne na nacionalnoj razini. Odredbe o privremenim mjerama (članak 18. i 19.), korektivnim mjerama (članak 12. i 13.) kao i druge mjere koje proizlaze iz odluke o meritumu spora (zahtjevi koji se mogu postaviti kod povrede poslovne tajne propisani su člancima 11., 14. i 15.) implementirani su tako da su prenesene u prvom redu odredbe Direktive 2016/943 kao lex specialis, a u manjem dijelu Direktive o provedbi prava, tamo gdje se one ne preklapaju s odredbama Direktive 2016/943. Primjerice Direktiva 2016/943 ne sadrži izričite odredbe o privremenim mjerama kojima bi se spriječile povrede poslovnih tajni na komercijalnoj razini, već je odredba o tim mjerama koju nalazimo u stavcima 2. i 3. članka 18. Zakona unesena radi implementacije Direktive o provedbi prava.

\subsection{Sporovi zbog zaštite poslovnih tajni nakon donošenja Direktive 2016/943}

Broj slučajeva povrede poslovnih tajni gotovo je nemoguće utvrditi. Naime često i zbog čuvanja svoje reputacije, tvrtke nisu sklone otkrivati da su bile žrtve nezakonitog pribavljanja, korištenja i otkrivanja poslovnih tajni, a jednako su tako suzdržane utužiti takve povrede. ${ }^{87}$

Osim toga, prije donošenja Direktive 2016/943 u mnogim državama članicama nisu postojala pravila namijenjena zaštiti poslovne tajne u okviru sudskog spora, čime su žrtve neovlaštenog pribavljanja poslovne tajne bile dodatno obeshrabrene zatražiti pravnu zaštitu sudskim putem. ${ }^{88}$ Stoga se odredba o očuvanju povjerljivosti poslovnih tajni tijekom sudskog postupka smatra jednom od ključnih odredaba Direktive 2016/943. Odredba o očuvanju povjerljivosti tijekom sudskog postupka sadržana je u članku 10. Zakona. Sukladno zahtjevima Direktive predviđa se ograničenje broja osoba koje mogu pristupiti ročištima i dokumentima iz spisa predmeta. Ograničenje toga kruga osoba samo na osobe nužne za osiguravanje poštenog suđenja trebalo bi spriječiti nekontroliranu diseminaciju tajnih podataka te otkrivanje poslovne tajne samo onim osobama koje su obvezatne na čuvanje tajnosti i koje dodatno izjavom potvrđuju da su upoznate s tom obvezom. Sudska odluka u verziji koja nije povjerljiva ne smije se širiti izvan toga kruga osoba, a iz nje se uklanjaju ili redigiraju odlomci koji sadrže poslovne tajne kako bi se pripremila nepovjerljiva verzija odluke koja se može javno objaviti. Predviđeni su i posebni oblici dostave podnesaka i odluka u takvom postupku, naime oni se mogu dostaviti isključivo poštom ili neposredno dostavom.

Hoće li odredba o očuvanju povjerljivosti poslovnih tajni tijekom sudskog

87 Prema Radnom dokumentu Komisije, (bilješka 12), str. 17, gdje se navodi da studije pokazuju da se radi o znatnom broju: 20 \%, odnosno svaka četvrta tvrtka u Europskoj uniji bila je žrtva barem jednog slučaja krađe povjerljivih informacija.

88 Iz obrazloženja Prijedloga direktive, (bilješka 8), str. 5. U Radnom dokumentu Komisije, (bilješka 12), str. 216., naglašen je problem očuvanja trajnosti informacija tijekom sudskoga postupka. Naime, poslovne tajne mogu biti otkrivene drugoj strani ili javnosti kao posljedica takvog postupka, što je osnovni razlog da su nositelji obeshrabreni da pokreću postupke radi zaštite poslovnih tajni. 
postupka, pa i ostale mjere, postupci i pravna sredstva predviđena Direktivom 2016/943 dovesti do povećanja broja sudskih predmeta u kojima se traži zaštita poslovnih tajni, ostaje za vidjeti. Priprema izvješća o trendovima u sudskim sporovima u pogledu nezakonitog pribavljanja, korištenja ili otkrivanja poslovne tajne u okviru primjene Direktive 2016/943 u nadležnosti je Ureda Europske unije za intelektualno vlasništvo (EUIPO), točnije Europske promatračnice za povrede prava intelektualnog vlasništva koja djeluju pri EUIPO-u i treba biti pripremljeno da 9. lipnja 2011. ${ }^{89} \mathrm{~S}$ obzirom na to da je tek godina dana prošla od roka za implementaciju direktive prerano je da bi se mogli sagledati njezini učinci.

No, na temelju propisa kojim se na federalnoj razini u SAD-u uređuje građansko pravna zaštita poslovnih tajni, ${ }^{90}$ a koji je sadržajno vrlo blizak Direktivi 2016/943 ${ }^{91}$ zabilježene su prve sudske odluke. U predmetu Dalmatia Import Group, Inc. v. FoodMatch, Inc. et al..$^{92}$ tužitelju je presudom dodijeljena naknada štete u iznosu većem od 2,500,000 USD, pri čemu je 500,000 USD na ime naknade štete zbog nezakonitoga pribavljanja i korištenja poslovne tajne, a radilo se tajnom receptu džema od smokava. Također podatci iz SAD-a pokazuju da je nakon što je 2016. godine na snagu stupio novi zakon zabilježeno $30 \%$ više sporova zbog povrede poslovnih tajni. ${ }^{93}$

Ovdje valja napomenuti da je upravo odgovarajući iznos dosuđene naknade štete presudan za učinkovitu zaštitu poslovnih tajni. Za razliku od povreda prava intelektualnog vlasništva koje ne utječu na postojanje zaštićenog isključivog prava, povredom poslovna tajna najčešće gubi svoj faktični monopol i time mogućnost daljnje zaštite. Pojednostavljeno, jednom otkrivena poslovna tajna ne može ponovo

89 Kao pripremu, EUIPO je proveo studiju „Osnovna odrednica za sudske sporove o poslovnim tajnama u Europskoj uniji, (engl. The Baseline of Trade Secrets Litigation in the EU Member States, koja pruža opis temeljnih značajki pravnih sustava u 28 država članica EU-a u području zaštite od nezakonitog pribavljanja, korištenja ili otkrivanja poslovnih tajni prije implementacije Direktive. Ti će podatci služiti kao usporedni kada će se procjenjivati pomak odnosno učinak primjene Direktive. Studija je objavljena u kolovozu 2018. godine, dostupno na: https://euipo. europa.eu/ohimportal/hr/web/observatory/news/-/action/view/4702225 (25. veljače 2019.).

90 Vidi bilješku 51.

91 Linton, K. C., The Importance of Trade Secrets: New Directions in International Trade Policy Making and Empirical Research, Journal of International Commerce and Economics, 2, rujan 2016., str. 9., navodi da je definicija poslovne tajne, kao i definicija nezakonitoga pribavljanja, korištenja i otkrivanja vrlo slična. Slične su i predviđene mjere, postupci i pravna sredstva, kao i mjere očuvanja povjerljivosti poslovnih tajni tijekom sudskog postupka. Osnovna je razlika što za razliku od američkoga zakona, Direktiva ne uređuje kaznenopravna aspekte odgovornosti.

92 Spor pred United States District Court for the Eastern District of Pennsylvania, (Docket No. 16-2767), dostupno na: https://www.crowelltradesecretstrends.com/2017/04/the-first-dtsaverdict-500000-for-misappropriation-of-a-fig-spread-recipe/ (25. veljače 2019.). Posebno je zanimljiva činjenica da se radi o proizvodu hrvatskoga poduzetnika koji se na hrvatskom tržištu nalazi pod žigom Dida Boža, više o tome: https://novac.jutarnji.hr/karijere/kako-samdidu-bozu-prodao-amerikancima-puno-ulazemo-u-popularizaciju-dalmatinske-price/7779144/ (25. veljače 2019.).

93 U usporedbi s približno 900 sporova godišnje u prethodnim razdobljima, u 2017. godini zabilježeno je čak 1.134 sporova zbog povrede poslovne tajne. Prema White, C., Trade secrets act increases US cases by 30\%, Intellectual Property Magazine, kolovoz 2018., dostupno na: https://www.intellectualpropertymagazine.com/patent/trade-secrets-act-increases-us-casesby-30-131239.htm (25. veljače 2019.). 
postati tajna, stoga gubi karakter intelektualnog vlasništva i u odnosu na sve treće postaje javno dostupna te nositelju više ne može pružati komercijalnu prednost na tržištu.

\section{ZAKLJUČAK}

Poslovne tajne kao oblik intelektualnog vlasništva imaju veliku važnost $u$ poslovanju i često se koriste za zaštitu inovacija jer u usporedbi s formalnim pravima intelektualnog vlasništva imaju određene prednosti. Prednosti se očituju u vremensko neograničenom trajanju faktičnog monopola nad sadržajem informacije koja se čuva tajnom te činjenici da zaštita ne pretpostavlja provođenje postupka registracije, pa stoga nije ni trošak. Međutim, iako se poslovnom tajnom mogu zaštititi najrazličitije vrste informacija pod uvjetom da su povjerljive, imaju komercijalnu vrijednost $\mathrm{i}$ poduzete su razumne mjere za očuvanje njihove povjerljivosti, njihova zaštita ne pruža se erga omnes, već se nositelj štiti od nezakonitog pribavljanja, korištenja i otkrivanja. Poslovne su tajne oblik neformalnog intelektualnog vlasništva kod kojeg ne nastaje subjektivno isključivo pravo kao što je to uobičajeno kod drugih prava intelektualnog vlasništva.

U cilju ujednačavanja pravne zaštite poslovnih tajni na unutarnjem tržištu Europske unije, doduše, samo u okviru građanskog prava, donesena je Direktiva EU 2016/943 o zaštiti neotkrivenih znanja i iskustva te poslovnih informacija (poslovne tajne) od nezakonitog pribavljanja, korištenja i otkrivanja. Iako su države članice Europske unije obvezatne Sporazumom TRIPS na pružanje zaštite poslovnih tajni $\mathrm{s}$ obzirom na to da je ta obveza vrlo načelna i općenita, postojale su velike razlike u načinu na koji su im države pružale zaštitu.

Direktiva u pogledu definicije poslovnih tajni i načela pružanja zaštite poslovnih tajni slijedi Sporazum TRIPS, ali razrađuje odredbe o opsegu zaštite poslovnih tajni propisivanjem što se smatra zakonitim, a što nezakonitim otkrivanjem, pribavljanjem ili korištenjem poslovnih tajni. Ipak i dalje je osnovni kriterij razgraničenja jesu li takve radnje počinjene u skladu ili protivno poštenim poslovnim praksama. $\mathrm{Na}$ sudskoj je praksi da tumači ove pojmove u primjeni, kao i druge bitne odrednice definicije, primjerice ima li informacija komercijalnu vrijednost, odnosno kvalificira li se informacija uopće za zaštitu u okviru intelektualnog vlasništva te koje će se mjere poduzete za zaštitu tajnosti smatrati razumnima. Važna će biti uloga suda i kod primjene predviđenih iznimaka kojima se želi osigurati ostvarivanje slobode izražavanja misli i izvještavanja, prava na pristup informacijama, zaštita zviždača i drugih legitimnih javnih interesa.

Važnost Direktive EU 2016/943 stoga je ponajprije u usklađivanju pravila građanskopravnog postupka predviđanjem mjera, postupaka i pravnih sredstava koje stoje na raspolaganju nositelju poslovne tajne u slučaju spora zbog povrede poslovne tajne, a koja su dodatno ujednačena Direktivom o provedbi prava intelektualnog vlasništva, ako države članice prošire njenu primjenu na nacionalnoj razini i na poslovne tajne. Također, nositeljima poslovne tajne osigurava se zaštita povjerljivosti informacija u okviru i tijekom sudskoga postupka. Pritom će iznosi dosuđene naknade 
štete imati presudnu važnost.

Primjena će pokazati je li Direktivom 2016/943 uspostavljen odgovarajući pravni okvir koji omogućava tvrtkama da nesmetano iskorištavaju i razmjenjuju svoje poslovne tajne na unutarnjem tržištu kako bi njihove inovacije dovele do gospodarskog razvoja i potaknule zapošljavanje, što je bio cilj harmonizacije ovoga pravnog područja.

\section{Knjige i članci:}

\section{LITERATURA}

1. Adamini, Sandra, Maarse, Hans, Versluis, Esther, Light, Donald, W., Policy Making on Data Exclusivity in the European Union: From Industrial Interests to Legal Realities, Journal of Health Politics, Policy and Law, 34, 6, 2009., str. 979-1010.

2. Bone, Robert G., Trade secrecy, innovation and reasonable secrecy precautions, u: Dreyfuss, Rochelle, C. i Strandburg, Katherine, J.(ur.), The Law and Theory of Trade Secrecy, A Handbook of Contemporary Research, Cheltenham, Edward Elgar Publishing, 2011., str. 46-76.

3. Cornish, William, Llewelyn, David, Intellectual property: Patents, Copyright, Trade Marks and Allied Rights, London, Sweet \& Maxwell, 2003.

4. Correa, Carlos, M., Test data protection, u: Dreyfuss, Rochelle, C. i Strandburg, Katherine, J.(ur), „The Law and Theory of Trade Secrecy, A Handbook of Contemporary Research, Edward Elgar Publishing, Cheltenham, 2011., str. 568-590.

5. First, Harry, Trade secrets and antitrust law, u: Dreyfuss, Rochelle, C., Strandburg, Katherine, J.(ur.), The Law and Theory of Trade Secrecy, A Handbook of Contemporary Research, Cheltenham, Edward Elgar Publishing, 2011., str. 332-380.

6. Turner, Jonathan C., Intellectual Property and EU Competition Law, Oxford, Oxford University Press, 2010.

7. Lemley, Mark A., The surprising virtues of treating trade secrets as IP rights, u: Dreyfuss, Rochelle, C. i Strandburg, Katherine, J.(ur.), The Law and Theory of Trade Secrecy, A Handbook of Contemporary Research, Cheltenham, Edward Elgar Publishing, 2011., str. 109-139.

8. Linton, Katherine Connor, The Importance of Trade Secrets: New Directions in International Trade Policy Making and Empirical Research, Journal of International Commerce and Economics, 2, rujan 2016. str. 1-17.

9. Long, Doris Estelle, Trade secrets and traditional knowledge: strengthening international protection of indigenous innovation, u: Dreyfuss, Rochelle, C. i Strandburg, Katherine, J.(ur.), The Law and Theory of Trade Secrecy, A Handbook of Contemporary Research, Cheltenham, Edward Elgar Publishing, 2011., str. 495- 536.

10. Matanovac, Romana, Građanskopravna zaštita prava intelektualnog vlasništva u odnosu prema Direktivi 2004/48/EZ o provedbi prava intelektualnog vlasništva - analiza stanja i nagovještaj promjena, u: Matanovac, Romana (ur.), Hrvatsko pravo intelektualnog vlasništva u svjetlu pristupa Europskoj uniji, Zagreb, Narodne novine/Državni zavod za intelektualno vlasništvo, 2006., str. 115-168.

11. Matanovac Vučković, Romana, Zbirka propisa u području prava intelektualnog vlasništva, Zagreb, Narodne novine, Državni zavod za intelektualno vlasništvo, 2008.

12. Meitinger, Ingo, Burri, Mira, Protection of Undisclosed Information, Commentary of Article 39 of the Agreement on Trade-Related Aspects of Intellectual Property Rights (TRIPS), u: Cottier, Thomas, Véron, Pierre (ur.), Concise International and European IP Law: TRIPS, Paris Convention, European Enforcement and Transfer of Technology, The Hague, Kluwer Law International, 2014. 
13. Miladin, Petar, Poslovna i profesionalna tajna kao pravo osobnosti, u: Zbornik radova: pravo na pristup informacija - Novalja, 30-31. svibnja 2008., Split, 2008.

14. Montagnon, Rachel, The Trade Secrets Directive: consistency of approach required, with or without Brexit, Journal of Intellectual Property Law and Practice, 11, 9, rujan 2016.

15. Peran, Branko, Goreta, Mirko, Vukošić, Kristina, Pojam i vrste tajni, Zbornik radova Veleučilišta u Šibeniku, br. 3-4/2015., str. 127-135.

16. Risch, Michael, Trade secret law and information development incentives, u: Dreyfuss, Rochelle, C., Strandburg, Katherine, J. (ur.), The Law and Theory of Trade Secrecy, A Handbook of Contemporary Research, Cheltenham, Edward Elgar Publishing, 2011., str. 152- 184.

17. Sandeen, Sharon, K., The limits of trade secret law: Article 39 of the TRIPS Agreement and the Uniform Trade Secret Act on which it is based, u: Dreyfuss, Rochelle, C., Strandburg, Katherine, J.,(ur.) The Law and Theory of Trade Secrecy, A Handbook of Contemporary Research, Cheltenham, Edward Elgar Publishing, 2011., str. 537- 567.

18. Van Overwalle, Geertrui, Uncorking trade secrets: sparking the interaction between trade secrecy and open biotechnology, u: Dreyfuss, Rochelle, C., Strandburg, Katherine, J. (ur.), The Law and Theory of Trade Secrecy, A Handbook of Contemporary Research, Cheltenham, Edward Elgar Publishing, 2011., str. 246-268.

19. Verona, Albert, Pravo industrijskog vlasništva, Zagreb, Informator, 1978.

\section{Pravni akti:}

Međunarodni ugovori

1. Agreement on Trade-Related Aspects of Intellectual Property Rights (Sporazum o trgovinskim aspektima prava intelektualnog vlasništva) od 15. travnja 1994.

2. Bernska konvencija za zaštitu književnih i umjetničkih djela od 9. rujna 1886.

3. Konvencija kojom se osniva Svjetska organizacija za intelektualno vlasništvo od 14. srpnja 1967.

4. Pariška konvencija za zaštitu industrijskog vlasništva od 20. ožujka 1883.

\section{Pravna stečevina Europske unije}

1. Direktiva (EU) 2016/943 Europskog parlamenta i Vijeća od 8. lipnja 2016. o zaštiti neotkrivenih znanja i iskustva te poslovnih informacija (poslovne tajne) od nezakonitog pribavljanja, korištenja i otkrivanja (Tekst značajan za EGP), SL L 157, 15.6.2016., str. $1-18$.

2. Direktiva 2004/48/EZ Europskog parlamenta i Vijeća od 29. travnja 2004. o provedbi prava intelektualnog vlasništva, SL L 157, 30.4.2004, str. 45-86.

3. Izjava Komisije o članku 2. Direktive 2004/48/EZ Europskog parlamenta i Vijeća o provedbi prava intelektualnog vlasništva (2005/295/EZ), SL L 94, 13.4.2005., str. 37.

4. Smjernice o određenim aspektima Direktive 2004/48/EZ Europskog parlamenta i Vijeća o provedbi prava intelektualnog vlasništva, COM/2017/0708 od 29.11.2017.

5. Uredba Komisije (EU) br. 316/2014 od 21. ožujka 2014. o primjeni članka 101. stavka 3. Ugovora o funkcioniranju Europske unije na kategorije sporazuma o prijenosu tehnologije, SL L 93, 28.3.2014., str. 17-23

Hrvatska, Republika

1. Kazneni zakon, NN, br. $125 / 11,144 / 12,56 / 15,61 / 15,101 / 17$ i 118/18

2. Zakon o izmjenama i dopunama zakona o lijekovima i medicinskim proizvodima dostupan na https://vlada.gov.hr/UserDocsImages//Sjednice/Arhiva//52-11.pdf (23. kolovoza 2018.)

3. Zakon o javnoj nabavi, NN, br. 120/16

4. Zakon o obveznim odnosima, NN, br. 35/05, 41/08, 125/1, 78/15 i 29/18 
5. Zakon o postupcima naknade štete zbog povreda prava tržišnog natjecanja, NN, br. $69 / 2017$

6. Zakon o pravu na pristup informacijama, NN, br. $25 / 13$ i 85/15

7. Zakon o radu, NN, br. 93/14 i 127/17

8. Zakon o tajnosti podataka, NN, br. $79 / 07$ i $86 / 12$

9. Zakon o trgovini, NN, br. 11/96, 75/99, 76/99, 62/01, 109/01, 49/03, 96/03 i 103/03

10. Zakon o trgovini, NN, br. 53/91, 77/92 i 26/93

11. Zakon o trgovini, NN, br. 87/08, 116/08, 76/09, 114/11, 68/13 i 30/14

12. Zakon o zaštiti neobjavljenih informacija s tržišnom vrijednosti, NN, br. 30/18.

13. Zakon o zaštiti prijavitelja nepravilnosti, NN, br. 17/19

14. Zakon o zaštiti tajnosti podataka, NN, br. 108/96

Sjedinjene Američke Države

1. Defend Trade Secrets Act, 18 U.S.C. $\$ 1836$

Sudska praksa:

1. Opći sud EU; predmet T-201/04, Microsoft protiv Europske komisije od 17. rujna 2007., EU:T:2007:289.

2. Opći sud EU; predmet T-353/94 Postbank protiv Europske komisije. od 18. rujna 1996., EU:T:1996:119

3. United States District Court for the Eastern District of Pennsylvania (Docket, No. 162767).

Službene publikacije:

1. Brant, Jennifer, Lohse, Sebastian, Trade secrets: Tools for innovation and collaboration, ICC Innovation and Intellectual Property Research Paper, 2014., br. 3.

2. Bux, Udo, Trade secrets, In-depth analysis: document requested by the URI Committee, Europski parlament, PE 493.055, Brussels, travanj 2014.

3. Corporate Europe Observatory (CEO), Adapting the EU Directive on Trade Secrets „Protection“ into National Law - A transposition guide for legislators and civil society organisations, veljača 2017.

4. Europska promatračnica za povrede prava intelektualnog vlasništva (EU Observatory) pri Uredu Europske unije za intelektualno vlasništvo (EUIPO): Studija „Intelektualno vlasništvo (IV) i rezultati malih i srednjih poduzeća za 2016. godinu“ (engl. „Intellectual property (IP) SME Scoreboard 2016")

5. Europska promatračnica za povrede prava intelektualnog vlasništva pri Uredu Europske unije za intelektualno vlasništvo (EUIPO): Studija „Zaštita inovacija putem poslovnih tajni i patenata: odrednice za poduzeća u Europskoj uniji“, dostupno na: http://www.stopkrivotvorinama-i-piratstvu.hr/files/file/pdf/studije/EUIPO_zastita_inovacija_poslovne tajne_patenti.pdf (20. veljače 2019.)

6. Europska promatračnica za povrede prava intelektualnog vlasništva pri Uredu Europske unije za intelektualno vlasništvo (EUIPO): Studija Osnovna odrednica za sudske sporove o poslovnim tajnama u Europskoj uniji (engl. The Baseline of Trade Secrets Litigation in the EU Member States), kolovoz 2018.

7. IPR Helpdesk, How to manage confidential business information, Fact Sheet, lipanj 2015.

8. Izvješće Odbora za obrazovanje, znanost i kulturu P.Z.E. br. 225 dostupno na: http://www. sabor.hr/radna-tijela/odbori-i-povjerenstva/izvjesce-odbora-za-obrazovanje-znanost-ikulturu-o-147 (14. veljače 2019.)

9. OECD, Enquiries Into Intellectual Property's Economic Impact, 2015.

10. Prijedlog Direktive o zaštiti neotkrivenih znanja i iskustava, te poslovnih informacija (poslovne tajne) od nezakonitog pribavljanja, korištenja i otkrivanja, $\operatorname{COM(2013)813,~}$ Brisel, 28. studenog 2013. godine 
11. Prijedlog zakona o zaštiti neotkrivenih informacija i iskustava te poslovnih informacija kojeg je Hrvatskom saboru 9. studenog 2017. godine podnijela Vlada Republike Hrvatske, dostupno na: https://www.sabor.hr/sites/default/files/uploads/sabor/2019-01-18/081314/ PZE 225.pdf (28. lipnja 2019)

12. Radni dokument Europske komisije, Procjena učinka Prijedloga direktive o zaštiti neotkrivenih znanja $\mathrm{i}$ iskustava, te poslovnih informacija (poslovne tajne) od nezakonitog pribavljanja, korištenja i otkrivanja, SWD (2013) 471 od 28. studenog 2013. godine

Vrela s interneta:

1. Andrews Jeffrey, Henessy, Erin, Morrison O'Connor, Nancy, Rhebergen, Constance, Carbone, Chelsea, Kendrick, Nick, Keep quiet and carry on under the EU trade Secrets Directive, Intellectual Property Magazine, rujan 2016., dostupno na: https://www. intellectualpropertymagazine.com/world/europe/keep-quiet-and-carry-on-under-the-eutrade-secrets-directive-119136.htm (14. veljače 2019.)

2. Coca Cola Journey, The Secret Is Out: Coca-Cola's Formula Is at the World of CocaCola, listopad 2012, dostupno na: https://www.coca-colacompany.com/stories/the-secretis-out-coca-colas-formula-is-at-the-world-of-coca-cola (14. veljače 2019.)

3. Hamidović, Haris, Nije zaštićeno? Ne može biti otuđeno!, OpeninfoTrend, 7, 2016, dostupno na: http://www.infotrend.hr/clanak/2016/7/nije-zasticeno-ne-moze-bitiotudeno!-,88,1258.html (23. kolovoza 2018.)

4. McMullen, Daniel, J., Torok, Gabriel, Recipe for reasonable measures, Intellectual Property Magazine, listopad 2016., dostupno na: https://www.intellectualpropertymagazine.com/ patent/recipe-for-reasonable-measures-119892.htm (14. veljače 2019.)

5. Moniruzzaman, Mohammad, Coca-Cola's Secret Formula: A Trade Secret Kept for More Than A Century, ožujak 2016, dostupno na: https://bdjls.org/coca-colas-secret-formulatrade-secret-kept-century/(14. veljače 2019.)

6. Nirwan, Prajwal, Trade secrets: the hidden IP right, WIPO Magazine, 6, prosinac, dostupno na: http://www.wipo.int/wipo_magazine/en/2017/06/article_0006.html (13. veljače 2019.)

7. Songer, Michael, Tehrani, Ali, The First DTSA Verdict: $\$ 500,000$ for Misappropriation of a Fig Spread Recipe, Crowell \& Moring LLP blog, travanj 2017, dostupno na: https://www.crowelltradesecretstrends.com/2017/04/the-first-dtsa-verdict-500000-formisappropriation-of-a-fig-spread-recipe/ (25. veljače 2019.)

8. Vrdoljak Jozo, privredni.hr, rujan 2018, dostupno na: https://novac.jutarnji.hr/ karijere/kako-sam-didu-bozu-prodao-amerikancima-puno-ulazemo-u-popularizacijudalmatinske-price/7779144/ (25. veljače 2019.)

9. White, Catherine, Trade secrets act increases US cases by $30 \%$, Intellectual Property Magazine, kolovoz 2018., dostupno na: https://www.intellectualpropertymagazine.com/ patent/trade-secrets-act-increases-us-cases-by-30-131239.htm (25. veljače 2019.) 


\section{Ana Rački Marinković*}

Summary

\section{PROTECTION OF BUSINESS SECRETS AS A TYPE OF INTELLECTUAL PROPERTY}

Concept of trade secrets is defined and the characteristics and specifics of trade secrets protection are explained. Trade secrets are considered in the context of intellectual property, and are compared to other, formal intellectual property rights. Protection of trade secrets on the international level is presented and the provisions of Directive /EU) 2016/943 on the protection of undisclosed know-how and business information (trade secrets) against their unlawful acquisition, use and disclosure are analysed as well as the reasons for its adoption. Importance of trade secrets protection for business, especially to foster innovation is highlighted. It is reviewed how the mentioned Directive was implemented in the Republic of Croatia and how the system of protection of trade secrets as a form of intellectual property was established by adopting the Act on the Protection of Undisclosed Information with Market Value. Finally, the application of the Directive on Enforcement of Intellectual Property Rights in cases of unlawful acquisition, use and disclosure of trade secrets is investigated. It is indicated that the significance of the EU Directive 2016/943 is primarily in the harmonization of the rules of civil procedure, while the jurisprudence will have an important role in the interpretation of the scope of protection of trade secrets and the application of foreseen exceptions.

Keywords: trade secrets; know-how; intellectual property; unfair competition.

Zussamenfassung

\section{SCHUTZ DER GESCHÄFTSGEHEIMNISSE ALS EINER FORM DES GEISTIGEN EIGENTUMS}

In Beitrag werden der Begriff des Geschäftsgeheimnisses sowie auch die Eigenschaften und die Besonderheiten des Schutzes der Geschäftsgeheimnisse definiert. Geschäftsgeheimnisse werden im Kontext des geistigen Eigentums betrachtet und mit anderen formellen Rechten des geistigen Eigentums verglichen. Der auf den Schutz der Geschäftsgeheimnisse bezogene völkerrechtliche Rahmen wird berücksichtigt und die Bestimmungen der Richtlinie (EU) 2016/943 über den Schutz vertraulichen Know-hows und vertraulicher Geschäftsinformationen

* Ana Rački Marinković, Ph.D., Office of the Agent of the Republic of Croatia before the European Court of Human Rights, armarinkovic@zastupnik-esljp.hr. 
(Geschäftsgeheimnisse) vor rechtswidrigem Erwerb sowie rechtswidriger Nutzung und Offenlegung sowie auch die Gründe für deren Erlassung werden analysiert. Die Wichtigkeit des Schutzes des Geschäftsgeheimnisses für die Geschäftsführung, insbesondere für Innovationsförderung, wird auch hervorgehoben. Es wird dargestellt, wie die genannte Richtlinie implementiert wurde und wie man das System des Schutzes der Geschäftsgeheimnisse als eine Form des geistigen Eigentums in der Republik Kroatien durch Erlassung des Gesetzes über den Schutz von unveröffentlichten Marktwert-relevanten Informationen gründete. Abschließend wird die Anwendung der Richtlinie über die Durchsetzung der Rechte des geistigen Eigentums bei Verletzung von Geschäftsgeheimnissen analysiert. Es wird auf die Wichtigkeit der Richtlinie (EU) 2016/943, vor allem bei der Harmonisierung der Regeln des Zivilprozesses, hingewiesen. Ebenfalls wird betont, dass die Rechtsprechung die bedeutende Rolle bei der Auslegung des Umfangs der Geschäftsgeheimnisse und der vorgesehenen Ausnahmen spielen wird.

Schlüsselwörter: Geschäftsgeheimnisse; Know-how; geistiges Eigentum; unfairer Handel.

Riassunto

\section{LA PROTEZIONE DEI SEGRETI COMMERCIALI QUALE FORMA DI PROPRIETÀ INTELLETTUALE}

Si definiscono le nozioni di segreti commerciali e si illustrano le caratteristiche e le peculiarità della protezione dei segreti commerciali. I segreti commerciali si analizzano nel contesto della proprietà intellettuale e si comparano con gli altri diritti formali della proprietà intellettuale. Si valuta altresì come la protezione dei segreti commerciali sia disciplinata sul piano internazionale e si disaminano le disposizioni della Direttiva EU 2016/943 sulla protezione del know-how riservato e delle informazioni commerciali riservate (segreti commerciali) contro l'acquisizione, l'utilizzo e la divulgazione illeciti, come pure i motivi della sua emanazione. Si tratta altresì della rilevanza della protezione dei segreti commerciali negli affari, in ispecie per il sostegno delle innovazioni. Si illustra in quale modo tale Direttiva sia stata attuata e come sia stata concepita la protezione dei segreti commerciali quale forma di proprietà intellettuale nella Repubblica di Croazia con l'emanazione della Legge sulla tutela delle informazioni commerciali riservate. Alla fine, si disamina l'applicazione della Direttiva su diritti di proprietà intellettuale in caso di violazione dei segreti commerciali. Si dimostra che l'importanza della Direttiva EU 2016/943 anzi tutto sta nell'armonizzazione delle regole del processo civile, mentre nell'interpretazione dell'ampiezza della tutela dei segreti commerciali e delle relative eccezioni un ruolo fondamentale verrà ricoperto dalla giurisprudenza.

Parole chiave: segreti commerciali; know-how; properieta' intellettuale; concorrenza sleale. 
